\title{
The East Kemptville tin deposit, Yarmouth County, southwestern Nova Scotia: a lithogeochemical study of the wallrock metasedimentary rocks
}

\author{
Daniel J. Kontak \\ Nova Scotia Department of Natural Resources, P.O. Box 698, Halifax, Nova Scotia B3J 2T9, Canada \\ and \\ Jarda Dostal \\ Department of Geology, St. Mary's University, Halifax, Nova Scotia B3H 3C3, Canada
}

\author{
Date Received November 27, 1991 \\ Date Accepted March 2, 1992
}

\begin{abstract}
The results of a petrographic and lithogeochemical study of metasedimentary rocks (Lower Paleozoic Meguma Group) surrounding the northern part of the East Kemptville tin deposit, southwestern Nova Scotia are presented. The metasedimentary rocks, including interbedded psammites and pelites, are fine-grained and highly indurated. Pelitic horizons contain hornfelsic textures (i.e., $\leq 5 \mathrm{~mm}$ cordierite grains) near the granite; sparse veining includes some cassiterite and sulphides. Hydrothermal alteration is manifested by disseminated, fine-grained, secondary muscovite and/or muscovite and chlorite infilling and lining microfractures with bleached haloes and associated cassiterite, sulphides, tourmaline, fluorite and carbonate.

The major and trace element chemistry, including the rare-earth elements, of the metasedimentary rocks are compared to different data bases that comprise: (1) averages for pelites and psammites of Phanerozic age, (2) nonmineralized Meguma Group rocks, and (3) fields in discriminant binary element diagrams. For most of the major and trace elements analyzed an apparently unaltered, normal chemistry is indicated, except for some LILE (e.g., Li, $\mathrm{Rb}, \mathrm{U}$ ) and ore-forming elements (e.g., $\mathrm{Sn}, \mathrm{Zn}, \mathrm{Bi}$ ) where enrichment is considered to reflect infiltration of mineralizing fluids from the proximal granite/greisen of the main deposit area. The data indicate that infiltration of fluids was minimal and that, for the most part, the metasedimentary rocks acted as an impermeable cap to the oreforming solutions.
\end{abstract}

Les résultats d'une étude pétrographique et lithogéochimique des roches métasédimentaires (Groupe de Meguma du Paléozoïque inférieur) entourant la partie nord du gisement d'étain de East Kemptville, dans le sud-ouest de la Nouvelle-Écosse, sont présentés. Les roches métasédimentaires, comprenant des grès et des pélites, sont à grain fin et fortement indurées. Les horizons pélitiques montrent des textures de cornéennes (i.e., des grains de cordiérite $<5$ $\mathrm{mm}$ ) près du granite; des veines éparses contiennent de la cassitérite et des sulfures. L'altération hydrothermale se manifeste par de la muscovite secondaire à grain fin disséminée ou par de la muscovite et de la chlorite en remplissage et en tapissage de microfractures aux épontes lessivées et associées à de la cassitérite, des sulfures, de la tourmaline, de la fluorite et des carbonates.

La composition en éléments majeurs et traces, incluant les terres rares, des roches métasédimentaires sont comparées à diverses bases de données, incluant: (1) les composition moyennes des pélites et des grès d’âge Phanérozoïque, (2) les roches non minéralisées du Groupe de Meguma et (3) les champs des diagrammes de discrimination binaires. Les teneurs de la plupart des éléments majeurs et traces analysés indiquent une composition normale, apparamment inaltérée, à part pour certains éléments à grand rayon ionique (e.g., Li, Rb, U) et certains éléments économiques (e.g., $\mathrm{Sn}, \mathrm{Zn}, \mathrm{Bi}$ ) où l'enrichissement est considéré comme représentant l'infiltration de fluides minéralisateurs provenant du greisen proximal de la région du gisement principal. Les données indiquent que l'infiltration des fluides était minimale et que les roches métasédimentaires ont agi principalement comme une enveloppe imperméable pour les solutions minéralisatrices.

[Traduit par le journal]

\section{INTRODUCTION}

The East Kemptville Sn-(Cu-Zn-Ag) deposit, located in Yarmouth County of southwestern Nova Scotia (Fig. 1), contained initial reserve estimates of 56 million tonnes of $0.165 \%$ Sn (Moyle, 1985). A significant resource of tin on a global scale, the deposit was discovered in the late 1970's and mining commenced in the fall of 1985 as a 18,000 tonne/day (9000 tonnes ore) open pit operation producing ca. 4000 tonnes of Sn concentrate per annum. The deposit ceased production on January 3,1992, in part reflecting the depressed price of tin.

The East Kemptville Sn-base metal deposit is entirely contained within a topaz-muscovite leucogranite body 


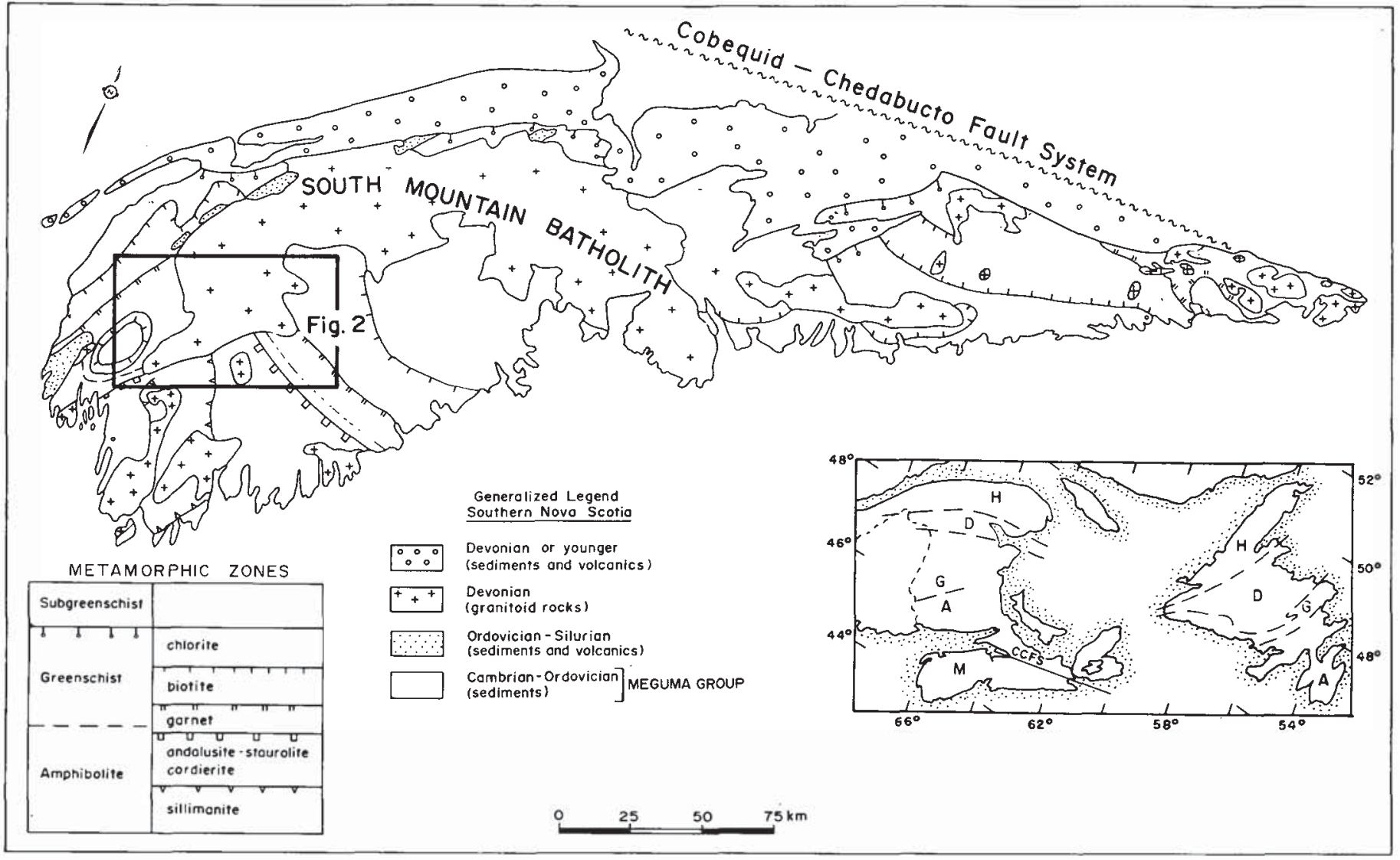

Fig. 1. Outline of southern Nova Scotia showing the regional geology of the Meguma Terrane with Davis Lake area of Figure 2 outlined. Inset shows the terranes which make up the Canadian Appalachians: H - Humber, D - Dunnage, G - Gander, A - Avalon, M - Meguma.

(Kontak, 1990a) which intruded metaturbiditic sedimentary rocks of the Lower Paleozoic Meguma Group. While considerable attention has been focused on the host leucogranite and mineralized greisens (Chatterjee and Strong, 1984; Chatterjee et al., 1985; Kontak, 1988, 1990a, 1990b, 1990c, 1991; Kontak and Cormier, 1991; Kontak and Chatterjee, in press; Richardson, 1983, 1988; Richardson et al., 1982, 1988,1990 a), the metasedimentary rocks of the wallrock have received limited attention. Richardson (1983) reported two chemical analyses each of mineralized metasedimentary rocks at the deposit site and unaltered rock away from the deposit. Kontak (1990c, in press) presented preliminary results of a lithogeochemical study of metasedimentary rocks collected from the northern end of the deposit area near the granite-metasedimentary rock contact.

In this paper, the more detailed results of this lithogeochemical study of the metasedimentary rocks are presented, together with petrographic observations. The primary concern of the study is to evaluate the role of the wallrocks in terms of the evolution of the mineralization at East Kemptville. As first noted by Richardson et al. (1982), the highly indurated nature of the metasedimentary rocks and general lack of significant alteration and associated mineralization within them suggests that they may have acted as an impermeable barrier to the mineralizing fluids. Thus, a lithogeochemical study may provide evidence by which to evaluate this hypothesis or, alternatively, determine if in fact some fluid migration out of the granite and into the country rock did occur. A corollary of this study is to determine the nature and extent of a primary dispersion halo about the deposit which may be of significance in terms of exploration for additional reserves and other mineralized centres.

\section{Regional Geological Setting}

The study area is located in the southern part of the Meguma Terrane (MT in Fig. 1) which is underlain predominantly by Lower Paleozoic metasedimentary and metavolcanic rocks that were deformed by the mid-Devonian Acadian Orogeny (Poole, 1967; Reynolds and Muecke, 1978; Keppie and Dallmeyer, 1987; Muecke et al., 1988) and subsequently intruded by meta- to peraluminous $370 \mathrm{Ma}$ granites (Clarke and Halliday, 1980; Reynolds et al., 1981). The northern part of the Meguma Terrane, south of the eastwest trending Cobequid-Chedabucto boundary fault (CCFS in Fig. 1; Keppie, 1982; Mawer and White, 1987), is underlain by Carboniferous and younger sedimentary rocks, part of the regional Maritime Basin of Atlantic Canada, that infilled successor basins after the regional Acadian deformation and plutonism.

The East Kemptville deposit area is located at the western margin of the large, $370 \mathrm{Ma}$, composite South Mountain Batholith (MacDonald et al., 1989, 1992). More specifically the deposit is located at the contact of the Davis Lake pluton 
and metasedimentary rocks of the Meguma Group (Fig. 2). The deposit area lies within the northeast-trending polymetallic Sn-base metal domain of Chatterjee (1983; see also Kontak et al., 1990) which includes several centres of variable mineralization associated with either granitic rocks [e.g., East Kemptville; Kempt Snare Lake (Soehl et al., 1989)] or metasedimentary rocks of the Meguma Group (e.g., Duck Pond deposit; Hattie 1989; Pitre and Richardson, 1989) (Fig. 2). Also of importance is the presence of a metalliferous-rich stratigraphic horizon referred to as the GHT or Goldenville-Halifax Transition Zone (Zentilli et al., 1986) which has been suggested to be important in terms of metallogeny both within the southwestern Nova Scotia tin domain and the auriferous Lower Paleozoic Meguma Group of the eastern Meguma Terrane (Sangster, 1990).

\section{Local Geological Setting}

The inset map in Figure 2 shows the outline of the deposit area which coincides with the leucogranite-metasedimentary rock. The area is shown in more detail in Figure 3 where the ore zones are indicated. The presence of roof pendants within the granite and the plunging nature of the granite-sediment contact to the northeast (about $30^{\circ}$ ) together suggest that the roof zone of the intrusion (i.e., magma chamber) is probably exposed. The northern contact of the granite and metasedi- mentary rocks is steeply dipping; in fact in most cases it is subvertical and in some locations coincides with a fault. This fault, referred to as the Contact fault by Richardson $e t$ al. (1988), hugs the northern contact and although coinciding with the lithological contact, may also cross-cut it, thus postdating the time of intrusion and mineralization. The fault probably formed during the main phase of post-plutonism deformation which affected most of the deposit area (Kontak, 1990a; Kontak et al., 1986; Kontak and Cormier, 1991).

The leucogranitic host rock has been described in detail by Kontak (1990a, 1991) and only a brief summary is presented here. It is a fine- to medium-grained, seriate textured topaz-muscovite leucogranite with variably developed penetrative deformational fabrics. There is a conspicuous absence of miarolitic cavities and related features (i.e., breccias, tuffisites, etc.), and pegmatites ( $\leq 1 \mathrm{~m})$ are restricted to a few rare localities. Thus, the leucogranite is considered to have intruded as a $\mathrm{H}_{2} \mathrm{O}$-undersaturated melt. Rare dykelets of leucogranite ( $<2-3 \mathrm{~cm}$ width) cut the metasedimentary rocks.

Mineralization consists of an early stage of massive and zoned topaz-cassiterite-bearing greisens which are cut by base-metal-rich quartz veins. The massive greisens are finegrained, dark grey to black and account for the majority of the tin mineralization; they contain approximately 0.2 to $0.4 \%$ $\mathrm{Sn}$ and variable quantities of base and precious $(\mathrm{Ag})$ metals. In contrast, the zoned greisens consist of $<5 \mathrm{~cm}$ to $1 \mathrm{~m}$ wide

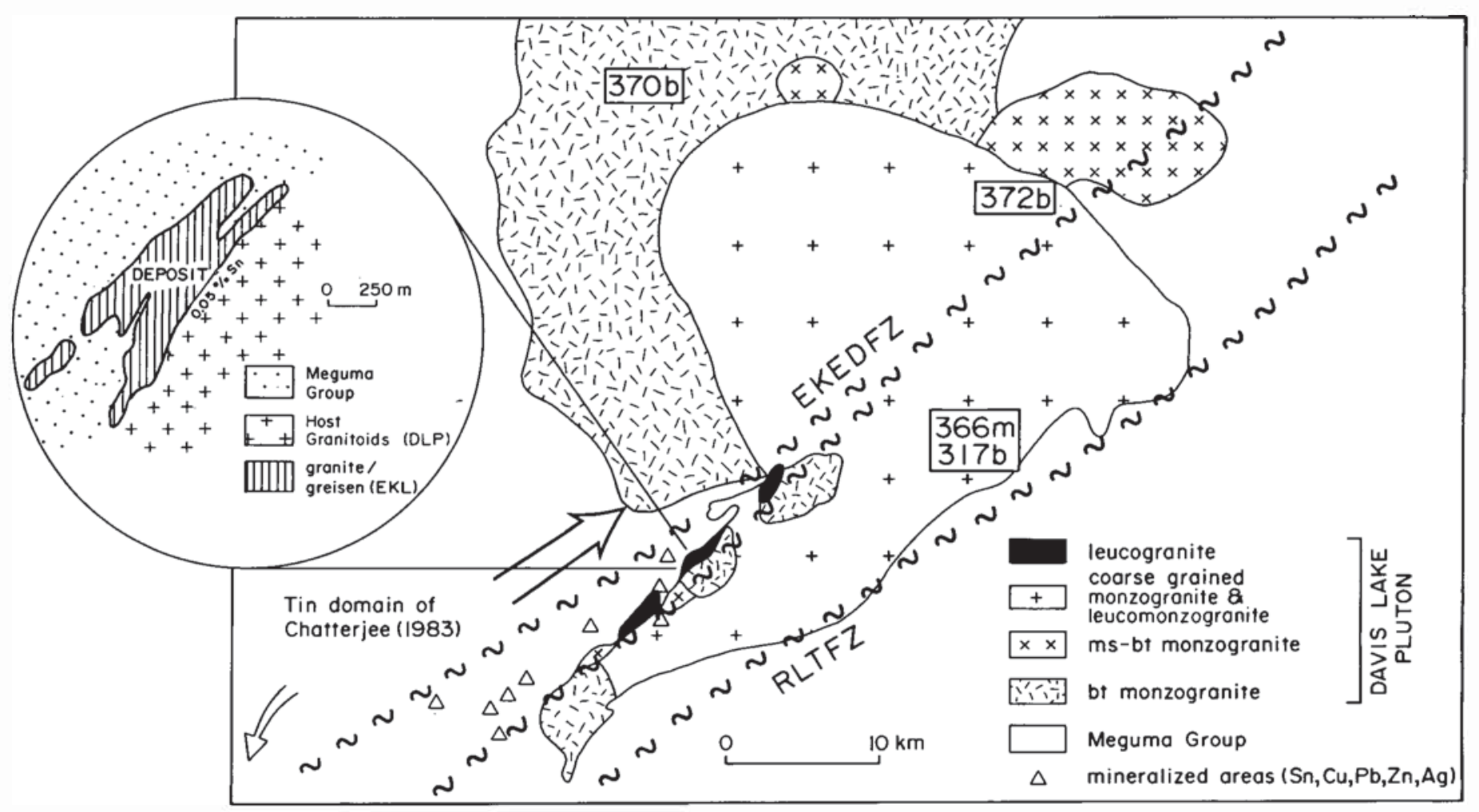

Fig. 2. Geology of the western part of the South Mountain Batholith (i.e., Davis Lake pluton; modified from MacDonald et al., 1989) showing: (1) the location and outline of the East Kemptville Sn-polymetallic deposit; (2) the outline of the tin domain of Chatterjee (1983) with the location of Sn-polymetallic occurrences/deposits in the Meguma Group; (3) location of the major regional structures East Kemptville East Dalhousie fault zone (EKEDFZ) and Rushmere Lake-Tobeatic fault zone (RLTFZ); and (4) location and ages of micas dated by the ${ }^{40} \mathrm{Ar} /{ }^{9} \mathrm{Ar}$ method (from Reynolds et al., 1981). 

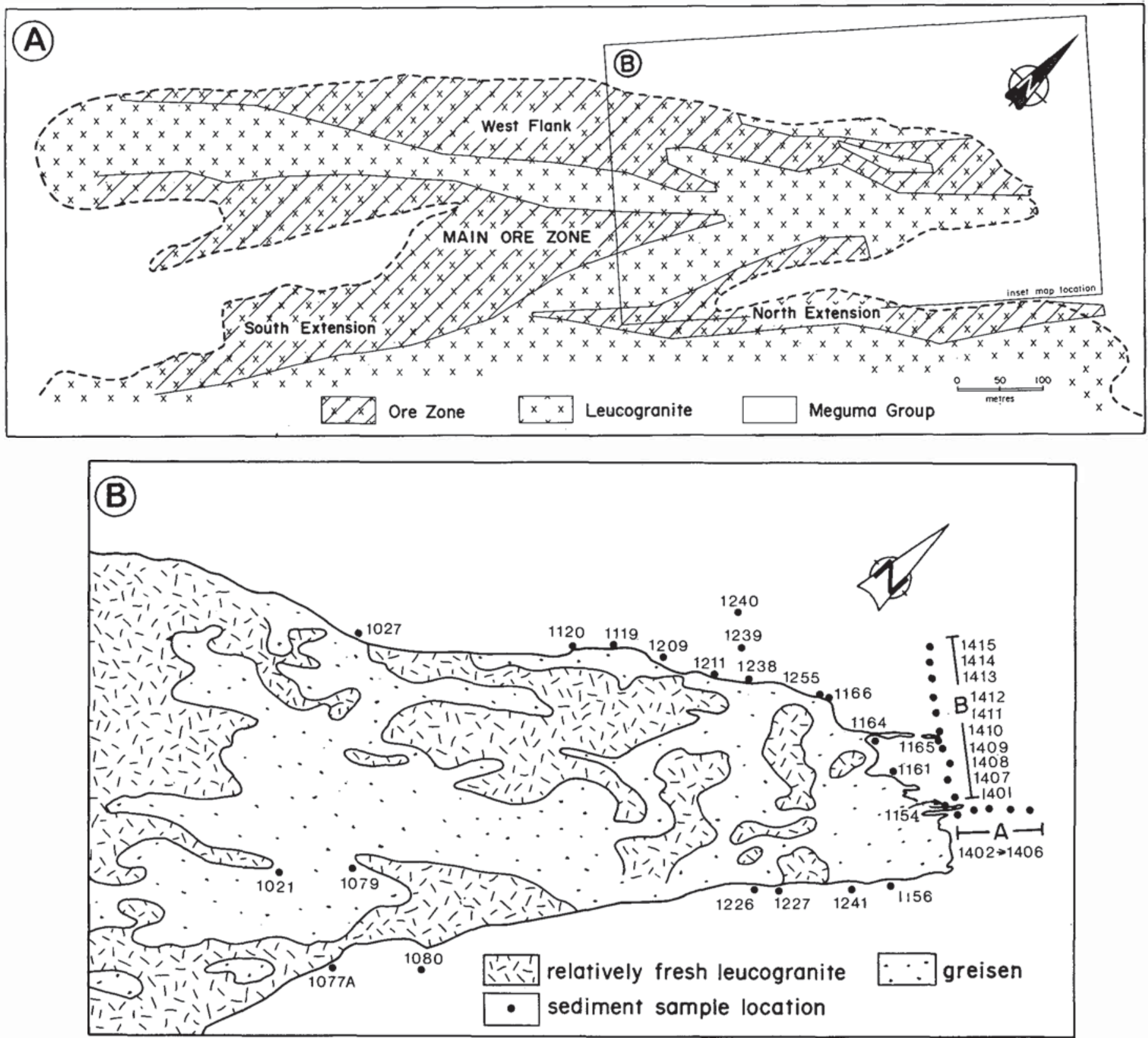

Fig. 3. Geological maps of the East Kemptville open pit deposit area showing: (1) simplified geology; (2) the outline of the mineralized zones; and (3) location of metasedimentary samples used in this study. The sections labelled A and B are discussed in the text.

zoned greisens cored by massive cassiterite- and topaz-rich zones. Further details of the mineralogy and geochemistry of the greisens, as well as the later base-metal rich quartz veins, can be found in Kontak et al. (1986), Kontak (1990c) and Richardson (1988). Mineralization in the metasedimentary rocks is rare, and consists of tin-bearing and sulphide-bearing veins of small $(<1 \mathrm{~cm}$ width) dimensions and extent (i.e., near the contact).

As Figure $3 \mathrm{~A}$ indicates, there is a general northeasterly trend to the ore zones and in a broad sense they generally coincide with the granite-metasediment contact. For example, as mining progressed at the deposit the extent of the Main Ore Zone decreased as the extent of the metasedimentary keel extending into the granite diminished in size; a similar situation would apply equally to the North and South Extension Ore zones.

The metasedimentary rocks enveloping the deposit are fine-grained, mixed psammites to pelites with the former dominating, and all rocks are generally highly indurated. Of the 36 samples collected, $50 \%$ are psammites, $34 \%$ pelites and the remainder semipelites; this is considered a good approximation of the proportion of lithologies present. Where $\mathrm{S}_{0}$ is observed it is moderately to steeply dipping and indicates a northeasterly-trending anticline extending through the area. The pelitic lithologies have a well-developed, subvertical slaty cleavage which may be cut by a second, flatlying spaced cleavage. In a few instances, narrow zones (i.e., $6-10 \mathrm{~cm}$ ) of intense deformation were observed, similar to the 
mylonitic zones in the granite (Kontak, 1990a; Kontak et al., 1986). Near the granite, hornfelsic textures are present in the pelites with abundant, elliptical-shaped, $5 \mathrm{~mm}$-size cordierite grains. Although bleaching and veining are not obvious in hand specimens, such features are observed in thin section and will be discussed below.

\section{Sampling of Metasedimentary Rocks}

Thirty-six samples of metasedimentary rock were collected from the northern part of the East Kemptville deposit area during detailed mapping in the summer of 1986 (Kontak et al., 1986). Sampling was designed to test for the possible presence and extent of a primary metal dispersion halo around the mineralized granite. Thus, the samples were collected along the granite-metasediment contact and along traverses away from and perpendicular to the northernmost contact (labelled A and B, respectfully, in Fig. 3). Two of the samples collected (EK-86-1021 and 1079) came from a roof pendant in the southeastern part of the study area. All the samples collected were free of megascopically visible signs of veining and alteration.

In addition to the metasedimentary rocks, two greisenized leucogranites (EK-1154, 1227) were included in the study to compare the alteration geochemistry in the greisenized granite with that in the metasedimentary rocks.

\section{Petrography of Metasedimentary Rocks}

The metasedimentary rocks are fine-grained, dark grey to black and generally highly indurated. Hornfels textures are generally uncommon except in the most aluminous rocks. Veining on a macroscopic scale is rare to absent and only occurs immediately adjacent to the granite. Bedding is only rarely observed because of the flat nature of the exposure and the apparent homogeneous nature of the sediments. Veins cutting the metasedimentary rocks include: (1) granitic dykelets ca. 1 to $3 \mathrm{~cm}$ wide, (2) a few cassiterite-rich (i.e., 50-80\%) veins ca. 0.5 to $1 \mathrm{~cm}$ wide, and (3) quartz-carbonate-sulphide veins (along the south end of the deposit only). Fractures mantled by narrow (1-3 mm) zones of bleaching are also present.

The metasedimentary rocks are composed predominantly of quartz, feldspars, biotite and muscovite with lesser carbonate, opaque minerals, tourmaline, apatite and zircon (Fig. 4a). The rocks are either dominated by detrital quartz and feldspar in a fine-grained, mica dominant matrix (psammites; Fig. 4a) or are composed of fine-grained phyllosilicates (pelites). The micas are of two distinct populations in terms of grain size. The coarser material may be of either regional metamorphic or contact metamorphic origin. The finer grained material probably reflects in part later hydrothermal alteration (see below). The rocks have at least one well-developed tectonic fabric $\left(\mathrm{S}_{1}\right)$; in some cases crenulations and C-S fabrics are observed. In a few samples chlorite-rich shear zones cross-cut the earlier, regional (?) $\mathrm{S}_{1}$ fabric. Porphyroblasts occur in only a few samples, are subrounded to ellipti- cal, and are generally replaced by muscovite \pm chlorite along the outer margins with a darker core area consisting of unidentified material.

It is rare for the metasedimentary rocks not to show signs of hydrothermal alteration, which includes the following features: (1) fine-grained white mica and orange-brown biotite which locally may replace most of the matrix (Fig. $4 \mathrm{~b}, \mathrm{e})$; (2) locally abundant tourmaline which overgrew the main fabric (Fig. 4f); (3) irregular patches of chlorite replacing the matrix; (4) fractures or veinlets (see below) of different types with or without ore minerals and with bleached margins (Fig. 4e,f); and (5) local disseminations of one or more of cassiterite, sphalerite, fluorite and carbonate which have no apparent proximity to veins or fractures. The most common of the aforementioned features observed are the formation of fine-grained muscovite which may replace considerable amounts of the matrix, and the presence of orange-brown biotite with abundant opaque minerals and rutile inclusions. The fine-grained muscovite and biotite are quite distinct texturally from the coarser metamorphic micas of either regional or contact metamorphic origin and are, therefore, considered to be of hydrothermal origin.

Veinlets $(1-3 \mathrm{~mm})$ which cross-cut the metasedimentary rocks consist of several varieties in terms of varying proportions of minerals, but these can be broadly grouped into two main types: (1) muscovite-rich, either fine- or coarse-grained, with associated \pm chlorite, cassiterite, ore minerals, tourmaline, carbonate (Fig. 4b,c,e,f); (2) chlorite \pm cassiterite, ore minerals, tourmaline (Fig. 4d). Where cross-cutting relationships could be observed (three cases), muscovite-bearing fractures were seen to offset and postdate chlorite-bearing fractures. Both veinlets generally have bleached margins where fine-grained muscovite or chlorite predominate. The veinlets are never abundant and in terms of modal mineralogy account for only trace amounts of the mineralogy of a typical thin section. Thus, where abundant hydrothermal mica has replaced the matrix, it must reflect pervasive passage of fluid along much finer channelways.

The combination of regional metamorphism, contact metamorphism, hydrothermal alteration and attendant mineralization and later superimposed shear deformation (Kontak and Cormier, 1991), makes it difficult to be more specific about the possibility of different generations of minerals without knowledge of mineral chemistry. Such work is in progress and will be reported elsewhere.

\section{Analytical Procedures}

Samples selected for chemistry were fine-grained veinfree rocks. All samples were first cleaned and weathered surfaces removed by sawing. Material was crushed to -200 mesh and all samples analyzed for major and trace element contents with eleven samples also analyzed for rare-earth elements (REE). Major elements were analyzed on fused disks and trace elements $(\mathrm{Rb}, \mathrm{Sr}, \mathrm{Ba}, \mathrm{V}, \mathrm{Cr}, \mathrm{Ni}, \mathrm{Cu}, \mathrm{Zn}, \mathrm{Ga}$, $\mathrm{Zr}, \mathrm{Nb}, \mathrm{Y}$,) on pressed powdered pellets using an automated Phillips X-ray fluorescence spectrometer at St. Mary's Uni- 

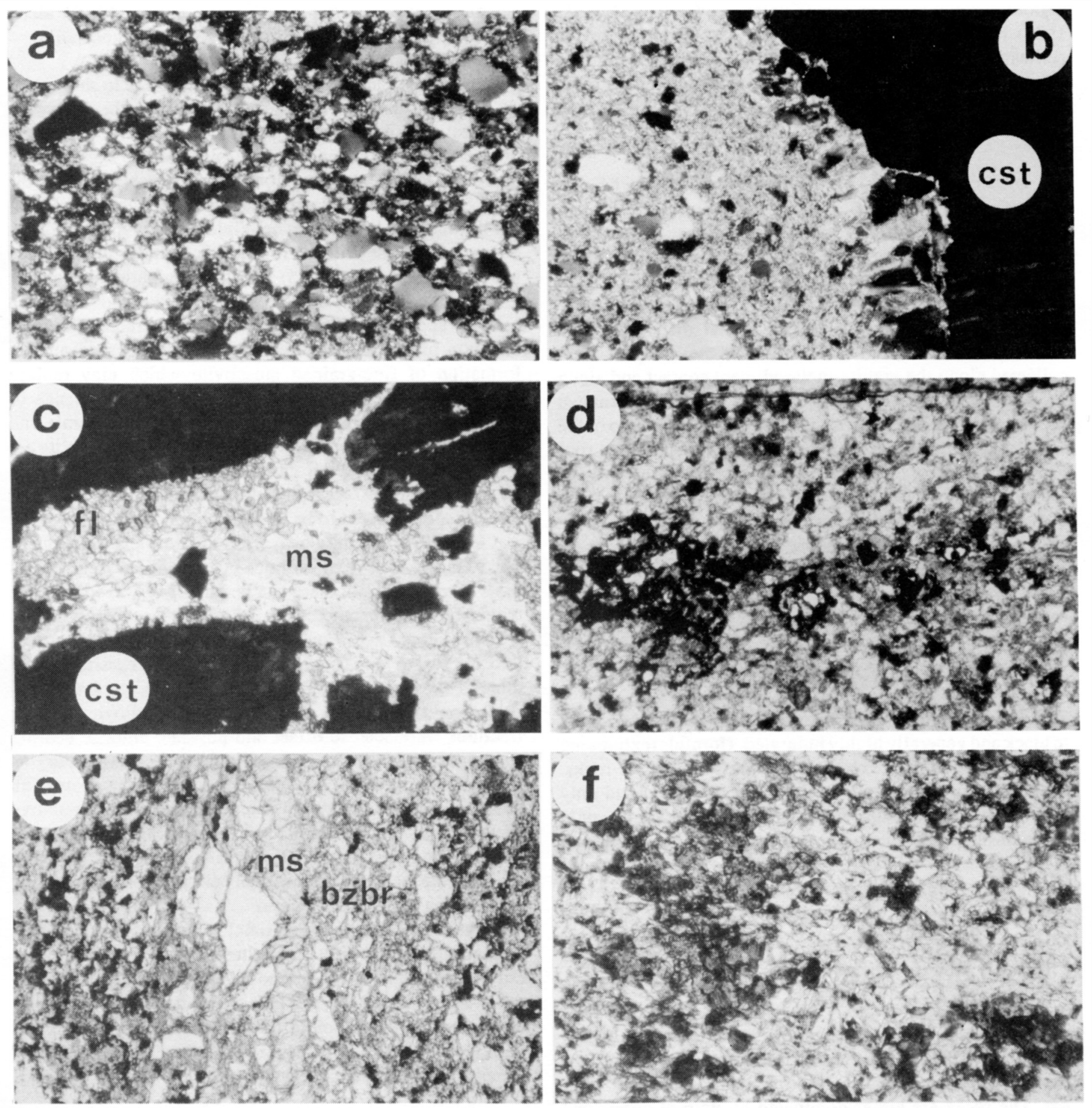

Fig. 4. Photomicrographs (field of view ca. $2 \mathrm{~mm}$ wide; transmitted light) of metasedimentary rocks at East Kemptville. (a) Unaltered psammite with coarse grains of quartz and feldspar in matrix of mica; note the weak foliation (horizontal) and sutured quartz grains. (b) Coarse cassiterite grain (cst) with coarse rosettes of muscovite growing towards the sericitized metasedimentary rock. Note that in the lower left corner some vestige of the former psammitic texture remains, but close to the cassiterite it has been replaced by fine muscovite. (c) Cassiterite (cst)-fluorite (fl)-quartz (clear)-muscovite (ms; intergrown with quartz) assemblage in psammitic rock. (d) Veinlet of chlorite with cassiterite and sulphides growing along it. Note the bleaching of the rock against the vein which has destroyed most of the pre-existing mica mineralogy. (e) Muscovite veinlet (ms) in psammite with symmetrically disposed border zone of bleached wallrock (bzbr). (f) Tourmaline-muscovite-rich area in psammite located adjacent to a granite dyke.

versity, Halifax, Nova Scotia. Additional trace elements (Sc, $\mathrm{Hf}, \mathrm{Ta}, \mathrm{Co}$ ) were analyzed by instrumental neutron activation along with the REE (La, Ce, Nd, Sm, Eu, Gd, Tb, Yb, Lu); samples were irradiated at the McMaster University reactor 
and counting done at St. Mary's University. Complete details of the analytical procedures, including estimates of precision and accuracy are given in Dostal et al. (1986). The remaining trace elements $(\mathrm{Li}, \mathrm{Mo}, \mathrm{W}, \mathrm{As}, \mathrm{Bi}, \mathrm{Ag}, \mathrm{Sb}, \mathrm{U}, \mathrm{Pb}$ ) were analyzed at Bondar-Clegg Company Limited, Ottawa, Ontario by inductively-coupled and DC plasma. We note that there appears to be a systematic enrichment in Gd for some unknown reason which is most apparent in the chondritenormalized diagrams where a prominent inflection occurs at this point.

\section{GeOChemistry}

The data have been subdivided into three populations based on wt. $\% \mathrm{SiO}_{2}:<60 \%, 60-70 \%$ and $>70 \%$ which correspond to psammites, semi-pelites and pelites, respectively, in terms of their petrographic features. The average \pm 1 standard deviation for each of these populations is presented in Table 1, along with representative analyses of different shale suites compiled from the literature and the two greisenized leucogranite samples. The averages and ranges of some metals $(\mathrm{Zn}, \mathrm{Cu}, \mathrm{As}, \mathrm{Sb}, \mathrm{W}, \mathrm{Sn}, \mathrm{Pb})$ are given in Table 2 for comparative purposes (see below). The complete list of geochemical data is available from the senior author upon request. The REE data are given in Table 3 along with the elemental ratios discussed in the text.

\section{Major Element Geochemistry}

Results of major element chemistry are summarized in Table 1 and graphically presented in Figures 5, 6 and 7. The three suites show consistent and systematic chemical variation with respect to the major elements such that there is a gradual change in elemental abundances from the pelites to the psammites. The data set is plotted in a series of binary element diagrams in Figure 5 using $\mathrm{Al}_{2} \mathrm{O}_{3}$ as the abscissa since it shows the largest overall range. In Figure 5 the other major elements are seen to show well defined positive $\left(\mathrm{TiO}_{2}\right.$, $\left.\mathrm{MgO}, \mathrm{Fe}_{2} \mathrm{O}_{3}, \mathrm{~K}_{2} \mathrm{O}, \mathrm{P}_{2} \mathrm{O}_{5}, \mathrm{LOI}\right)$ or negative $\left(\mathrm{SiO}_{2}, \mathrm{Na}_{2} \mathrm{O}\right)$ correlations; calcium appears to behave independently. The excellent covariations observed in Figure 5 are typical of major element chemistry of sedimentary rocks (e.g., Feng and Kerrich, 1990; Pan et al., 1991) and reflect systematic changes in mineralogy. The two altered leucogranites plot away from the well-defined trends established for the metasedimentary rocks and there appears to be no tendency for the sedimentary rock data to trend toward that of the greisens as a result of alteration.

In Figure 6 the data are plotted in the binary discrimination diagrams of Bhatia (1983); these diagrams are based on a compilation of data for greywackes. The deviation of the pelite data from the identified fields is to be expected because the diagrams are designed for clastic rocks; however, the pelite data are included to illustrate the continuity of the chemistry from psammite to pelite regardless of the binary plot used. The psammite data conform to the fields for continental island arc (B) and active continental margin (C) which are consistent with the generally inferred paleotectonic setting for these rocks. Thus, in general the data conform to major element chemistry for greywackes suggesting that their chemistry has not been modified despite their proximity to a mineralized centre. Again, there appears to be no tendency for the sedimentary chemistry to trend toward that of the greisen samples.

The major element chemistry of the pelites is compared to some average shale compositions in Table 1 . As one might expect, the variation of provenance, depositional environment and diagenetic history have contributed to the differences in the chemistry of the suites. However, the Bendigo shale average is remarkable similar to the pelites, except for relative differences in $\mathrm{Na}_{2} \mathrm{O}$ and LOI, suggesting again that the chemistry of the rocks may not have been modified significantly.

A final comparison of the chemistry for the East Kemptville data set is made with the average compositions of similar rock types in the greenschist facies from the eastern Meguma Terrane as compiled by Douma (in prep.). In Figure 7 the average compositions are normalized to Douma's data and there appears to be a very close correspondence between the two data sets, with even slight relative enrichments and depletions observed being identical for both data sets.

\section{Trace Element Geochemistry}

The average trace element geochemistry for the three groupings are summarized in Table 1 and we note the general absolute enrichment of $\mathrm{Rb}, \mathrm{Zn}, \mathrm{Cu}$ and $\mathrm{Sn}$ and the high percent relative deviation associated with these elements. We also note that these elements and also $\mathrm{Bi}, \mathrm{Li}$ and $\mathrm{W}$ are enriched relative to the average compositions of similar rocks from the eastern Meguma Terrane (Fig. 7).

\section{$\mathrm{Rb}, \mathrm{Sr}, \mathrm{Ba}, \mathrm{Li}$ and $\mathrm{Ga}$}

There is a strong positive correlation between wt. $\% \mathrm{~K}_{2} \mathrm{O}$ and $\mathrm{Rb}, \mathrm{Ba}, \mathrm{Li}$ and $\mathrm{Ga}$, while $\mathrm{Sr}$ shows a poorly defined negative correlation. These trends are substantiated by the averages shown in Table 1 and the correlations suggest that these elements essentially reside in micas. With respect to $\mathrm{Rb}, \mathrm{Sr}$, and $\mathrm{Ba}$ the data are plotted in Figure 8 and the following points noted. (1) There is no correlation between $\mathrm{Rb}$ and $\mathrm{Sr}$ (Fig. 8A) and whereas the $\mathrm{Sr}$ contents are comparable to other suites [NASC, AWS, PCS in Fig. 8A; see also Nathan (1976), Scratch et al. (1984), Feng and Kerrich (1990), Wintsch et al. (1991)], the absolute Rb contents and $\mathrm{Rb} / \mathrm{Sr}$ ratios (up to 24 ) are anomalously high compared to the aforementioned suites. Note how the greisen samples are also characterized by elevated $\mathrm{Rb} / \mathrm{Sr}$ ratios. In contrast, the $\mathrm{Ba}$ versus Sr plot (Fig. 8B) separates the data such that the pelites are characterized by $\mathrm{Ba} / \mathrm{Sr}$ of about 3 to 10 while the psammites have $\mathrm{Ba} / \mathrm{Sr}$ of mostly $<3$; note that this distinction is mainly based on the enrichment of the pelites in $\mathrm{Ba}(>500$ $\mathrm{ppm})$. Although the $\mathrm{Ba}$ values are elevated relative to the averages shown in Figure 8B, comparable levels of enrich- 
Table 1. Whole rock geochemistry for Meguma Group metasediments, East Kemptville deposit.

\begin{tabular}{|c|c|c|c|c|c|c|c|c|c|c|c|c|c|}
\hline \multirow{2}{*}{ 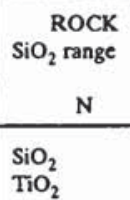 } & \multicolumn{2}{|c|}{$\begin{array}{c}\text { Pelite } \\
(<60 \%) \\
\mathrm{X}_{ \pm}(13)\end{array}$} & \multicolumn{2}{|c|}{$\begin{array}{c}\text { Semi-Pelite } \\
(60-70 \%) \\
\mathrm{X}_{6}(1 \sigma)\end{array}$} & \multicolumn{2}{|c|}{$\begin{array}{c}\text { Psammite } \\
(>70 \%) \\
\mathrm{X}_{ \pm}(17) \\
\end{array}$} & \multirow{2}{*}{$\begin{array}{r}\text { Greisen } \\
\text { EK-86- } \\
1227 \\
72.35 \\
0.03\end{array}$} & \multirow{2}{*}{$\begin{array}{c}\text { Greisen } \\
\text { EK-86- } \\
1154 \\
\begin{array}{c}70.6 \\
0.04\end{array}\end{array}$} & \multirow{2}{*}{$\begin{array}{c}\text { AwS } \\
\\
\begin{array}{c}58.9 \\
0.78\end{array}\end{array}$} & \multirow{2}{*}{$\begin{array}{c}\text { NASC } \\
\begin{array}{r}64.82 \\
0.79\end{array}\end{array}$} & \multirow{2}{*}{$\begin{array}{r}\text { BSA } \\
\begin{array}{r}57.42 \\
0.74\end{array}\end{array}$} & \multirow{2}{*}{$\begin{array}{c}\text { PCS } \\
\begin{array}{c}626 \\
0.73\end{array}\end{array}$} & \multirow{2}{*}{$\begin{array}{r}\text { wss } \\
\begin{array}{r}54.31 \\
0.67\end{array}\end{array}$} \\
\hline & $\begin{array}{r}56.25 \\
0.87\end{array}$ & $\begin{array}{l}(1.94) \\
(0.07)\end{array}$ & $\begin{array}{r}66.37 \\
0.71\end{array}$ & $\begin{array}{l}(2.01) \\
(0.07)\end{array}$ & $\begin{array}{r}74.39 \\
0.55\end{array}$ & $\begin{array}{l}(2.57) \\
(0.07)\end{array}$ & & & & & & & \\
\hline $\mathrm{Al}_{2} \mathrm{O}_{3}$ & 19.43 & (1.12) & 15.13 & (1.39) & 11.70 & (1.07) & $\begin{array}{r}14.90 \\
0\end{array}$ & $\begin{array}{r}0.04 \\
15.11\end{array}$ & $\begin{array}{l}0.18 \\
16.7\end{array}$ & $\begin{array}{r}0.79 \\
16.88\end{array}$ & 20.08 & 15.6 & 18.61 \\
\hline $\mathrm{Fe}_{2} \mathrm{O}_{3}$ & 7.97 & $(0.91)$ & 6.02 & (1.12) & 3.92 & $(0.79)$ & 1.37 & 1.38 & 6.96 & 6.41 & 7.32 & 6.1 & 8.43 \\
\hline $\mathrm{MnO}$ & 0.15 & $(0.02)$ & 0.14 & $(0.03)$ & 0.10 & $(0.02)$ & 0.08 & 0.03 & 0.09 & 0.07 & 0.05 & 0.06 & 0.08 \\
\hline $\mathrm{MgO}$ & 3.39 & (0.31) & 2.53 & (0.22) & 1.89 & $(0.20)$ & 0.89 & 1.18 & 2.6 & 286 & 3.46 & 242 & 8.08 \\
\hline $\mathrm{CaO}$ & 0.90 & (0.39) & 0.41 & (0.30) & 0.73 & (0.24) & 1.21 & 2.27 & 2.2 & 3.68 & 0.20 & 0.50 & 0.61 \\
\hline $\mathrm{Na}_{2} \mathrm{O}$ & 2.20 & $(0.57)$ & 2.63 & (0.84) & 3.35 & $(0.70)$ & 3.71 & 2.26 & 1.6 & 1.12 & 0.44 & 1.4 & 0.71 \\
\hline $\mathrm{K}_{2} \mathrm{O}$ & 5.05 & $(0.96)$ & 3.33 & (0.67) & 2.15 & $(0.72)$ & 2.75 & 4.04 & 3.6 & 3.87 & 5.00 & 4.65 & 2.09 \\
\hline $\mathrm{P}_{2}^{2} \mathrm{O}_{5}$ & 0.22 & $(0.08)$ & 0.17 & $(0.01)$ & 0.14 & $(0.04)$ & 0.40 & 0.34 & 0.6 & 0.17 & 0.12 & 0.13 & 0.10 \\
\hline LOI & 2.82 & $(0.40)$ & 2.20 & $(0.40)$ & 1.16 & $(0.36)$ & 1.80 & 2.5 & 6.3 & NA & 5.80 & 5.9 & 5.94 \\
\hline$\Sigma$ & 99.26 & $(0.47)$ & 99.62 & $(0.49)$ & 100.10 & $(0.57)$ & 99.55 & 99.75 & 100.33 & 100.67 & 100.63 & 100.09 & 99.63 \\
\hline \multicolumn{14}{|c|}{ Trace Elements (ppm): } \\
\hline $\mathrm{Ba}$ & 940 & (135) & 560 & (139) & 332 & (164) & 53 & 219 & 580 & 63.6 & . & 492 & 444 \\
\hline $\mathrm{Rb}$ & 571 & (317) & 510 & (191) & 375 & (194) & 656 & 753 & 140 & 125 & - & 174 & 83 \\
\hline Sr & 159 & (77) & 101 & (89) & 177 & (51) & 123 & 42 & 300 & 142 & - & 69 & 73 \\
\hline $\mathrm{Y}$ & 52.0 & (15.1) & 42.5 & (12.8) & 34 & (11.7) & 43 & 49 & - & 35 & - & 25 & 25 \\
\hline $\mathrm{Z}_{\mathrm{r}}$ & 158 & (15.3) & 162 & (17.8) & 193 & (43.2) & 23 & 18 & - & 200 & - & • & 120 \\
\hline $\mathrm{Nb}$ & 12.9 & (1.4) & 11.6 & $(2.6)$ & 8.3 & (1.4) & 37 & 40 & . & 13 & . & - & 8 \\
\hline $\mathrm{Pb}$ & 15.4 & (18.9) & 28.8 & $(42.1)$ & 12.7 & (7.5) & 39 & 10 & . & - & - & 22 & 14 \\
\hline $\mathrm{G}_{\mathbf{a}}$ & 25.8 & $(2.1)$ & 18.6 & (1.8) & 14.1 & (2.7) & 34 & 36 & . & . & . & 20 & - \\
\hline $\mathrm{Zn}$ & 240 & (1.53) & 357 & (195) & 25.6 & (211) & 1085 & 945 & - & - & . & 114 & . \\
\hline $\mathrm{Cu}$ & 54.5 & (46) & 88.5 & (62.2) & 73.1 & (46) & 386 & 279 & - & - & . & 75 & - \\
\hline $\mathrm{Ni}$ & 51.7 & (8.7) & 32.5 & (6.1) & 19.5 & (4.4) & 7 & 8 & 68 & 58 & . & 57 & 520 \\
\hline $\mathrm{v}$ & 138 & (15.5) & 94.3 & (10.5) & 69.2 & (9.9) & $s$ & 5 & . & 130 & . & 188 & 183 \\
\hline$c r$ & 131 & (28.0) & 101 & $(9.9)$ & 85.5 & (6.5) & 35 & 28 & 90 & 125 & . & 105 & 1195 \\
\hline $\mathrm{Li}$ & 398 & (106) & 265 & (88) & 266 & (152) & 224 & 181 & . & . & - & - & . \\
\hline Mo & 3.2 & (2.6) & 2.1 & (2.6) & 3.4 & (2.9) & 9 & 13 & - & . & - & 4.5 & . \\
\hline w & 10.5 & (1.0) & 10.3 & $(0.7)$ & 12.3 & (7.3) & 24 & 24 & - & - & - & $\cdot$ & - \\
\hline As & 17.3 & (14.1) & 27.5 & (25.3) & 40.5 & (99) & 5 & 5 & . & 28 & . & 23 & . \\
\hline $\mathrm{Bi}$ & 3.9 & (1.9) & 3.6 & (1.1) & 4.5 & (1.8) & 3 & 28 & - & . & - & . & - \\
\hline$A_{B}$ & 0.5 & (0.08) & 0.5 & $(0.0)$ & 0.5 & $(0.0)$ & 0.5 & 0.5 & . & . & . & 0.41 & - \\
\hline Sb & 7.3 & (3.6) & 5.6 & $(0.9)$ & 5.2 & $(0.5)$ & $s$ & 8 & . & 2.0 & . & 1.3 & . \\
\hline U & 10.0 & $(0.0)$ & 10.0 & $(0.0)$ & 10.0 & $(0.2)$ & 24 & 15 & 3.7 & 2.6 & - & 5.9 & 1.7 \\
\hline Sn & 87.4 & $(39.0)$ & 68.3 & (20.2) & 138 & (144) & 172 & 281 & . & 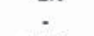 & . & 2.6 & . \\
\hline$A_{B}$ & 8.5 & (8.5) & 10.9 & $(-)$ & 6.2 & (3.7) & 1.5 & 2.2 & 13 & 14.6 & - & 16 & 27 \\
\hline $\mathrm{Hf}$ & 3.3 & (2.4) & 4.7 & $(\cdot)$ & 4.9 & (3.4) & 2.1 & 2.1 & 2.8 & 6.3 & . & - & 3.6 \\
\hline $\mathrm{Th}$ & 10.3 & $(0.9)$ & 7.0 & (.) & 6.0 & (2.8) & 4.6 & 3.8 & 12 & 12.3 & . & . & 4.7 \\
\hline $\mathrm{Ta}$ & 1.6 & $(0.2)$ & 1.0 & (.) & 0.8 & $(0.4)$ & 11.3 & 19.3 & 2.8 & 1.1 & - & - & 0.6 \\
\hline$c_{0}$ & 15.0 & (1.2) & 6.9 & (-) & 5.0 & (3.1) & 0.4 & 2.6 & 19 & 27 & . & 22 & 59 \\
\hline
\end{tabular}

Note that for some elements $(\mathrm{Hf}, \mathrm{Th}, \mathrm{Ta}, \mathrm{C})$ the $\mathrm{X} \pm 1 \sigma$ values are based on 2 pelites, 1 semipelite and 6 psammites only. AWS $=$ average world shale from Wedepohl (in Nathan, 1976)

NASC $=$ North American shale composite from Gromet et al. (1984).

BSA $=$ argillite; from Bhatia (1985) for Bendigo metaturbidites, Australia.

PSC = average Aphebian shale $(n-326)$ of the Canadian Shield from Cameron and Garrels (1980).

WSS $=$ Witwatersrand Supergroup, Booysens shale (Wronkiewicz and Condie, 1987). 
Table 2. Some ranges and averages for metals in sedimentary rocks.

\begin{tabular}{|c|c|c|c|c|c|c|c|c|}
\hline Mo & $\mathrm{Zn}$ & $\mathrm{Cu}$ & As & $\mathrm{Sb}$ & W & Sn & $\mathrm{Pb}$ & Reference \\
\hline - & $50-150$ & $3-80$ & ${ }^{1} 1-170$ & $0.1-0.7$ & - & - & $2-24$ & Feng and Kerrich (1990) \\
\hline- & $2-180$ & $3-28$ & - & - & - & - & $118-82$ & Maas and McCulloch (1991) \\
\hline - & $48-120$ & $1-13$ & - & - & - & - & $12-30$ & Floyd and Leveridge (1987) \\
\hline 2 & $74 \pm 9$ & $11 \pm 3$ & - & - & - & - & $15 \pm 1$ & Bhatia and Crook (1986) \\
\hline 3 & $52 \pm 8$ & $8 \pm 3$ & - & - & - & ـ & $24 \pm 1$ & Bhatia and Crook (1986) \\
\hline - & - & - & 28.4 & 2.0 & 2.1 & - & - & NASC; Gromet et al. (1984) \\
\hline${ }^{4} 2.2$ & 323 & 66 & 46 & 1.2 & - & 3.2 & 26 & PCS; Cameron and Garrels (1980) \\
\hline 54.5 & 114 & 75 & 23 & 1.3 & - & 2.6 & 22 & PCS; Cameron and Garrels (1980) \\
\hline 62.6 & 100 & 35 & 13 & 1.5 & - & 4 & 21 & Cameron and Garrels (1980) \\
\hline 7. & $37-77$ & $0-34$ & $5-70$ & $0-90$ & - & - & $13-23$ & Scratch et al. (1984) \\
\hline 8 & $52-111$ & $0-46$ & $7-61$ & $3-110$ & - & - & $18-31$ & Scratch et al. (1984) \\
\hline 9. & 95 & 45 & 10 & 1.5 & 1.8 & - & 20 & Vine and Tourtelot (1970) \\
\hline - & - & - & - & - & 4.6 & 3.3 & - & Beer and Ball (1986) \\
\hline $10_{-}$ & $181 \pm 20$ & $175 \pm 42$ & $175 \pm 42$ & - & $18 \pm 3$ & $36 \pm 6$ & - & Polya (1988) \\
\hline
\end{tabular}

${ }^{1}$ only 2 analyses $>50 \mathrm{ppm}$

2 average for continental island arc sediments

3 average for active continental margin

${ }^{4}$ Archean weighted average $(n=406)$

${ }^{5}$ Aphebian weighted average $(n=326)$

6 average Phanerozoic shale (Cameron and Garrels, 1980)

7 greywackes (unmineralized)

8 argillites (unmineralized)

9 average shale

${ }^{10}$ data for altered sediments (schists) $0-1 \mathrm{~km}$ from ore body (Panasqueira W-Sn deposit, Portugal)

${ }^{11}$ only 3 analyses $>44 \mathrm{ppm}$

Table 3. Rare earth element geochemistry for Meguma Group metasediments, East Kemptville deposit.

\begin{tabular}{|c|c|c|c|c|c|c|c|c|c|c|c|}
\hline Sample & $\begin{array}{c}\text { EK-86- } \\
1407\end{array}$ & $\begin{array}{c}\text { EK-86- } \\
1021\end{array}$ & $\begin{array}{c}\text { EK-86- } \\
1079\end{array}$ & $\begin{array}{c}\text { EK-86- } \\
1406\end{array}$ & $\begin{array}{c}\text { EK-86- } \\
1240\end{array}$ & $\begin{array}{c}\text { EK-86- } \\
1227\end{array}$ & $\begin{array}{l}\text { EK-86- } \\
1255\end{array}$ & $\begin{array}{c}\text { EK-87- } \\
1410\end{array}$ & $\begin{array}{r}\text { EK-86- } \\
1077 \mathrm{~A}\end{array}$ & $\begin{array}{c}\text { EK-86- } \\
1414\end{array}$ & $\begin{array}{c}\text { EK-86- } \\
1154\end{array}$ \\
\hline $\mathrm{La}$ & 30.00 & 37.10 & 29.10 & 36.40 & 17.70 & 3.04 & 21.30 & 25.00 & 21.85 & 23.47 & 3.36 \\
\hline $\mathrm{Ce}$ & 66.30 & 74.60 & 57.10 & 73.70 & 36.30 & 10.70 & 44.50 & 52.70 & 45.70 & 46.90 & 10.60 \\
\hline Nd & 30.40 & 33.80 & 26.80 & 34.30 & 16.90 & 7.26 & 19.30 & 23.20 & 21.40 & 21.70 & 6.10 \\
\hline $\mathrm{Sm}$ & 5.73 & 6.61 & 5.12 & 6.10 & 3.13 & 1.53 & 3.77 & 4.16 & 3.80 & 3.97 & 1.42 \\
\hline $\mathrm{Eu}$ & 1.35 & 1.50 & 1.13 & 1.18 & 0.67 & 0.14 & 0.68 & 0.86 & 0.77 & 0.98 & 0.21 \\
\hline Gd & 6.71 & 6.22 & 4.44 & 6.69 & 4.19 & 2.66 & 3.87 & 4.51 & 3.95 & 3.85 & 2.78 \\
\hline $\mathrm{Tb}$ & 0.92 & 0.90 & 0.75 & 0.88 & 0.53 & 0.24 & 0.57 & 0.58 & 0.52 & 0.59 & 0.23 \\
\hline $\mathrm{Yb}$ & 2.77 & 2.59 & 2.18 & 2.55 & 1.50 & 0.27 & 1.76 & 1.84 & 1.58 & 1.61 & 0.84 \\
\hline Lu & 0.43 & 0.37 & 0.30 & 0.36 & 0.24 & ND & 0.27 & 0.28 & 0.27 & 0.28 & 0.10 \\
\hline 乏REE & 144.61 & 163.69 & 126.92 & 162.16 & 81.16 & 25.84 & 96.02 & 113.13 & 99.84 & 103.35 & 25.64 \\
\hline$(\mathrm{La} / \mathrm{Lu})_{\mathrm{N}}$ & 7.15 & 10.28 & 9.94 & 10.36 & 7.56 & - & 8.08 & 9.15 & 8.29 & 8.59 & 3.44 \\
\hline$\left(\mathrm{Eu} / \mathrm{Eu}^{*}\right)_{\mathbb{N}}$ & 0.67 & 0.72 & 0.73 & 0.57 & 0.57 & 0.21 & 0.54 & 0.61 & 0.61 & 0.77 & 0.32 \\
\hline$(\mathrm{Gd} / \mathrm{Yb})_{\mathrm{N}}$ & 1.94 & 1.92 & 1.63 & 2.10 & 2.24 & 10.27 & 1.76 & 1.96 & 2.00 & 1.92 & 2.65 \\
\hline$\% \mathrm{SiO}_{2}$ & 56.46 & 58.66 & 69.09 & 70.61 & 76.42 & 72.35 & 71.00 & 77.69 & 70.70 & 76.03 & 70.60 \\
\hline
\end{tabular}

Pelites: EK-86-1407, 1021; Semipelite: EK-86-1079; Psammites: EK-86-1406, 1240, 1255, 1410, 1077A, 1414; Greisens: EK-86-1154, 1227 

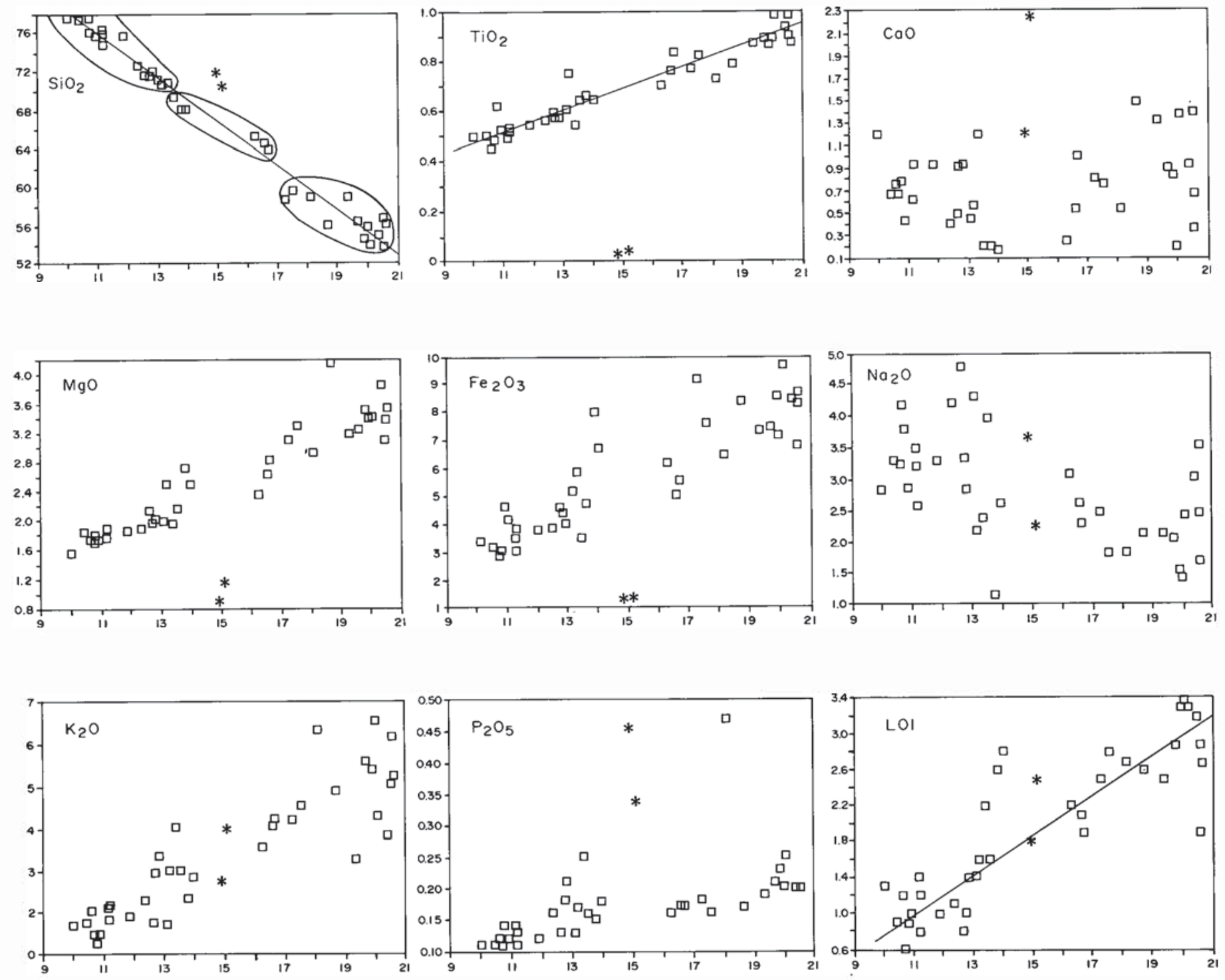

Fig. 5. Binary element diagrams for major element geochemistry of the East Kemptville metasedimentary rocks ( $\square$ ) and greisens $\left({ }^{*}\right)$. Abscissa is wt. $\% \mathrm{Al}_{2} \mathrm{O}_{3}$ in all the plots. In the top left plot the fields of psammites, semipelites and pelites are outlined (from left to right, respectively) and the two greisens are indicated by the asterisk. Note the generally good correlation of elements and lack of dispersion toward the two greisen samples.

ment are found in other sedimentary suites (Scratch et al., 1984; Sawyer, 1986; Feng and Kerrich, 1990; Wintsch et al., 1991). However, in these latter cases the Ba enrichment is generally followed by elevated $\mathrm{Sr}$ due to the presence of detrital feldspar.

There are few $\mathrm{Li}$ analyses available in the literature for comparison, but Cameron and Garrels (1980) list some for Precambrian shales from the Canadian Shield. The 100 to 700 ppm Li levels in the East Kemptville rocks are well above the 40 to $70 \mathrm{ppm}$ averages for Archean, Aphebian and Phanerozoic shales reported by these authors. We also emphasize that both greisen and leucogranite (Kontak, 1990a), and micas from both greisens and leucogranite (Kontak, 1991) show enrichment in Li.

\section{Ferromagnesian elements $(\mathrm{Cr}, \mathrm{V}, \mathrm{Ni}, \mathrm{Co}, \mathrm{Sc})$}

The ferromagnesian or transition elements show a progressive enrichment from psammitic through semipelitic to pelitic lithologies, as is typical of these elements in sedimentary rocks (Table 1 and below). There is a strong positive covariation in all the ferromagnesian trace elements with $\mathrm{MgO}$, total $\mathrm{Fe}$ and $\mathrm{TiO}_{2}$ (e.g., Fig. 9B) as expected. In terms of the absolute abundances of the ferromagnesian elements, levels of enrichment comparable to other Meguma Group samples (Fig. 7), the NASC (Gromet et al., 1984; Table 1) and other Lower Paleozoic sedimentary lithologies (Nathan, 1976; Scratch et al., 1984; Floyd and Leveridge, 1987; Wintsch et al., 1991). However, the samples are depleted in 


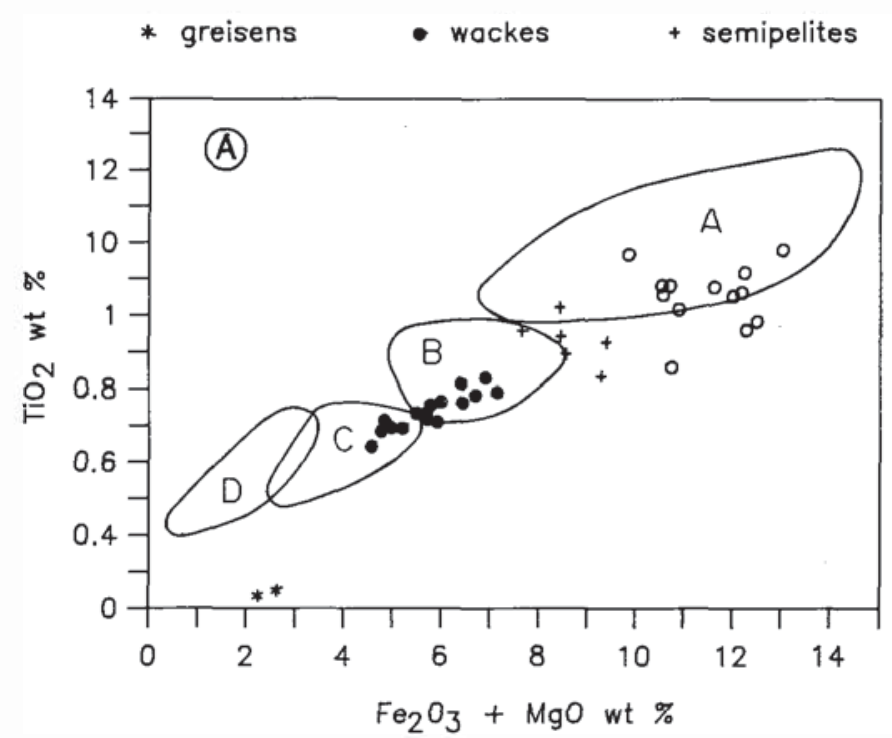

$\circ$ pelites
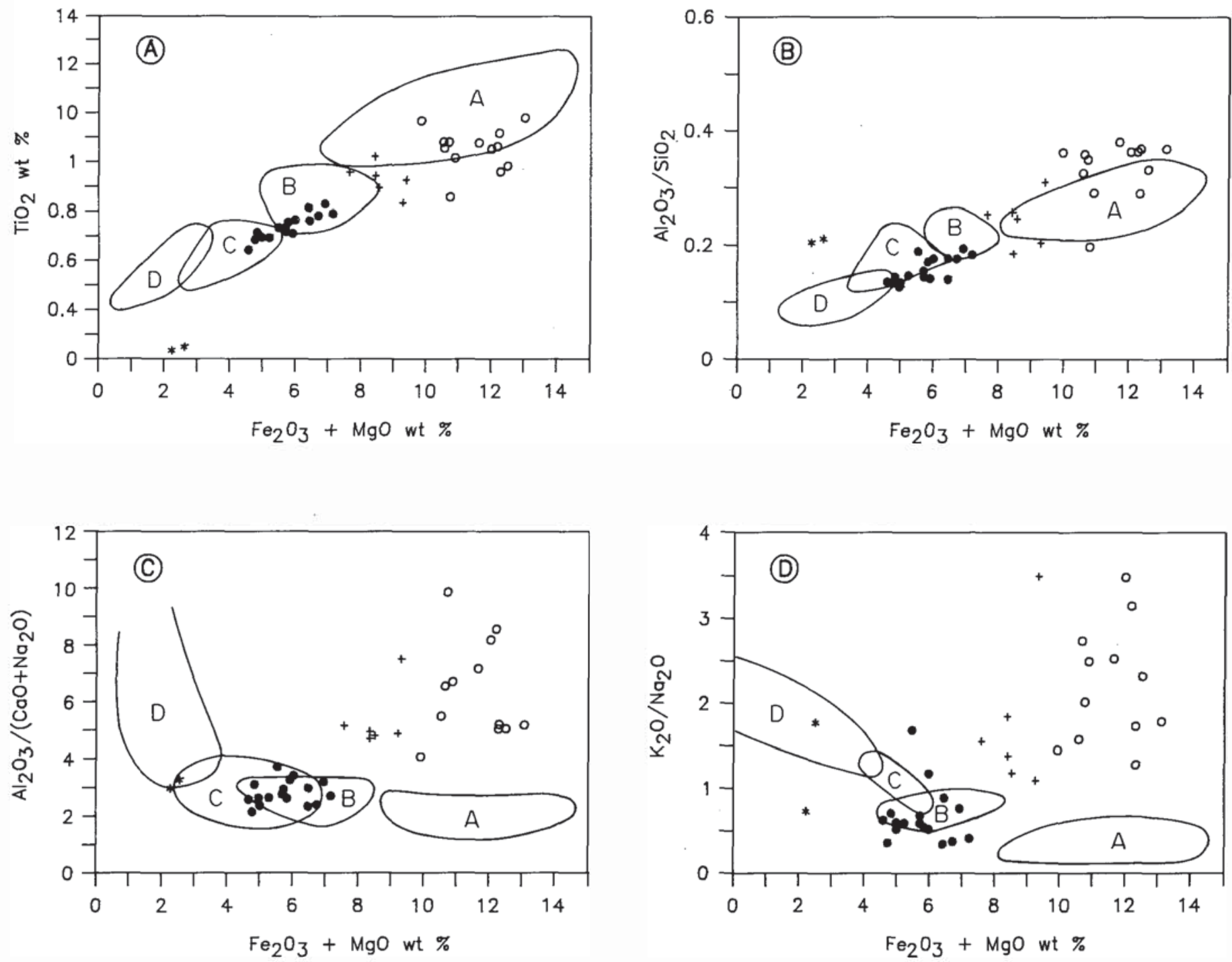

Fig. 6. Major element discrimination plots for the East Kemptville metasedimentary rocks and greisens (modified after Bhatia, 1983). Fields labelled are as follows: A - oceanic island arcs, B - continental island arcs, C - active continental margin, D - passive margin. Note that the wackes/psammites fall in the same field on all plots and have not been dispersed due to hydrothermal alteration.

these elements with respect to what is found in Archean rocks (Taylor and McLellan, 1985; see also AWS in Table 1). In Figure 9A the samples are plotted in the Cr versus Ni diagram and, although not shown, the data fall in the field defined for Paleozoic sediments (Taylor and McLellan, 1985). Note too, that in Figure 9A and all other binary element diagrams (plots of $\mathrm{TiO}_{2}, \mathrm{Cr}, \mathrm{Sc}$ and $\mathrm{Ni}$ versus $\mathrm{V}$ ) there are continuous trends. Compared to the NASC (Table 1) there are similar elemental abundances and also ratios for $\mathrm{Cr} / \mathrm{V}, \mathrm{Ni} / \mathrm{V}, \mathrm{Sc} / \mathrm{V}$ and $\mathrm{Co} / \mathrm{V}$ $(0.5,0.83,0.21,0.08$ versus $0.96,0.44,0.10,0.20$ for the Meguma Group versus NASC, respectively).

As with other trace elements, the two greisen samples deviate from the above trends and averages for the metasedimentary rocks. In this case, there is considerable depletion of these samples with respect to the ferromagnesian elements, similar to that found in the fresh leucogranite (Kontak, 1990a).

\section{High field strength elements (Hf, Ta, Y, Nb, Zr), $\mathrm{U}$ and $\mathrm{Th}$}

These elements are generally considered to be resistant to weathering and alteration processes (Taylor and McLellan, 1985; Bhatia and Crook, 1986), and thus can provide reliable estimates of original chemical variation. In the East Kemptville lithologies there is slight enrichment of Th, Nb, Y and $\mathrm{Zr}$ in the psammites over the pelite while $\mathrm{Ta}, \mathrm{Hf}$ and $\mathrm{U}$ remain fairly constant (Table 1). The absolute levels of elemental enrichment, exclusive of $U$, are comparable to most post-Archean suites (e.g., Nathan, 1976; Scratch et al., 

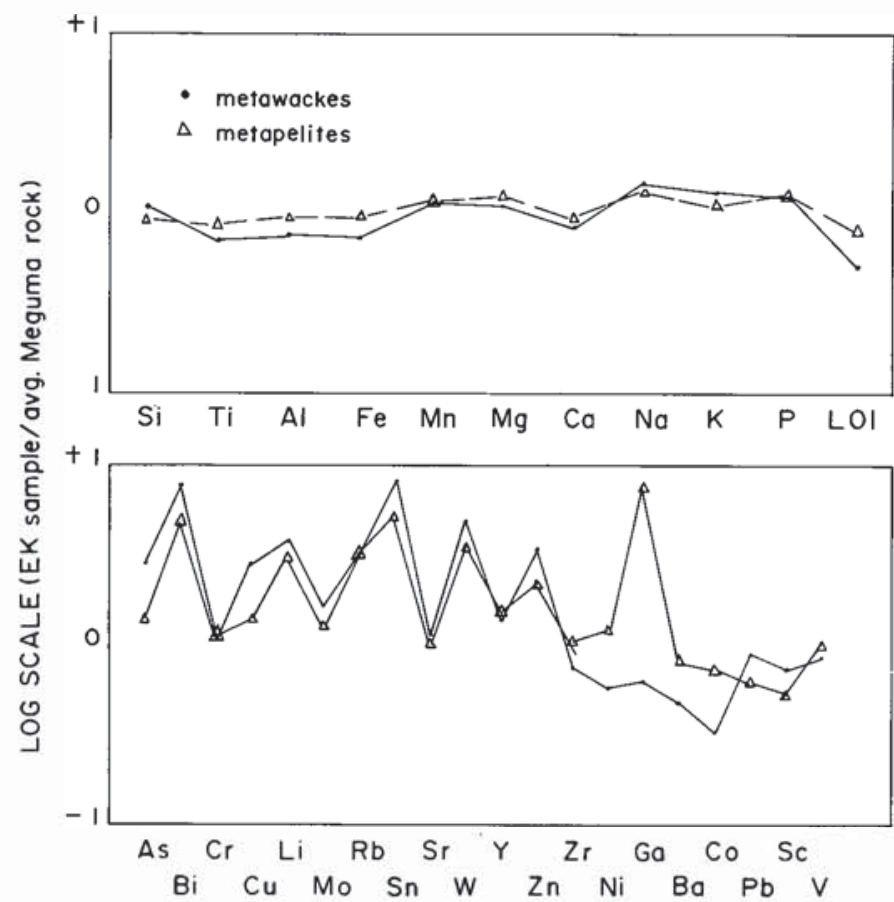

Fig. 7. Normalized spidergram plots for average pelite and psammite compositions from East Kemptville deposit area. The data in Table 1 are normalized to the average compositions of Meguma Group lithologies using the data of Douma (in prep.). Note the coherent behaviour of the data sets with similar relative enrichment and depletion compared to Douma's data set.

1984; Floyd and Leveridge, 1987) and some Archean suites for the HFSE only (e.g., Feng and Kerrich, 1990; Maas and McCulloch, 1991). Most notable is the elevated absolute enrichment of $\mathrm{U}$ at $10 \mathrm{ppm}$ for all lithologies and consequently depressed $\mathrm{Th} / \mathrm{U}$ and $\mathrm{K} / \mathrm{U}$ ratios of $0.6-1.0$ and $<4100$, respectively. These ratios compare to the normal Th/U and $\mathrm{K} /$ U ratios of 3-4 and 8000-12000, respectively, for the NASC, AWS (Table 1) and crustal averages (Taylor and McLellan, 1985; McLellan and Taylor, 1991).

In the two greisens there is considerable enrichment and depletion with respect to the HFSE, $U$ and Th (Table 1), with average concentrations of $\mathrm{U}(18 \mathrm{ppm}), \mathrm{Ta}(15 \mathrm{ppm})$ and $\mathrm{Nb}$ $(39 \mathrm{ppm})$ well above those seen in the metasedimentary rocks whereas $\mathrm{Zr}(21 \mathrm{ppm})$ and $\mathrm{Th}(4.2 \mathrm{ppm})$ are depleted relative to the metasedimentary rocks.

\section{$\mathrm{Sn}, \mathrm{Cu}, \mathrm{Zn}, \mathrm{Pb}, \mathrm{Ag}, \mathrm{Mo}, \mathrm{W}, \mathrm{As}, \mathrm{Bi}, \mathrm{Sb}$}

The ore forming and related elements (ORFE) at the East Kemptville deposit show highly variable degrees of enrichment between samples when compared to the average Meguma Group metasedimentary rock (Fig. 7). Table 2 lists some typical values of the ORFE for comparative purposes. Bismuth, $\mathrm{Ag}, \mathrm{Mo}$, and $\mathrm{Sb}$ are near or below their respective detection limits (note that $S b$ values are artificially inflated because of the high detection limit, i.e., $10 \mathrm{ppm}$ ) and show no enrichment. Lead is similar in its lack of enrichment in any lithology and shows typical background abundances com-
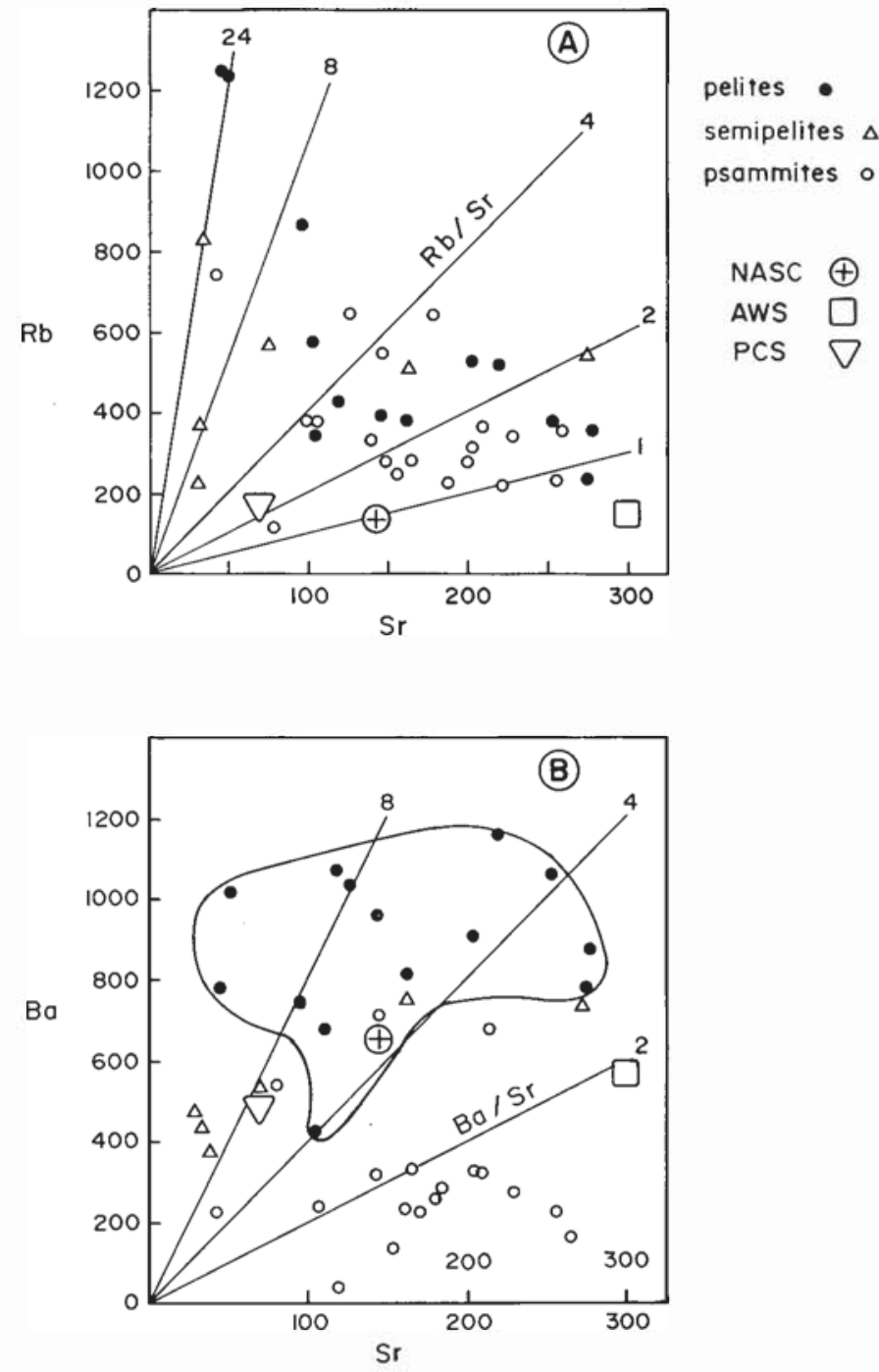

Fig. 8. Binary element diagrams for $\mathrm{Rb}$ and $\mathrm{Ba}$ versus $\mathrm{Sr}$ for the East Kemptville metasedimentary rocks and greisens. The average compositions plotted for comparative purposes are the NASC (Gromet et al., 1984), AWS (data in Nathan, 1976) and PCS (Cameron and Garrels, 1980); see Table 1 for data.

pared to the data in Table 2 . In contrast, $\mathrm{Zn}, \mathrm{Cu}, \mathrm{W}$ and $\mathrm{Sn}$ are variably enriched and show large variances in the data because of the erratic nature of mineralization; hence, elemental abundances vary from background levels to 100 's of ppm (e.g., Sn at about $500 \mathrm{ppm}$ ). Compared to the background levels tabulated in Table 2, the enrichment factors are approximately as follows: $\mathrm{Sn}=20-50 ; \mathrm{W}=2 ; \mathrm{Zn}=2-5 ; \mathrm{Cu}=1$ 10.

In Figure 10 binary element diagrams illustrate the relationship between $\mathrm{Sn}$, the base metals and $\mathrm{Rb}$ (representative of the LILE): (1) the best correlation is between $\mathrm{Zn}$ and $\mathrm{Cu}$, and to a lesser degree $\mathrm{Zn}$ and $\mathrm{Sn}$; (2) the most elevated $\mathrm{Sn}$ values are for the altered leucogranites and these are associated with depleted levels of $\mathrm{Zn}, \mathrm{Cu}$ and $\mathrm{Rb}$; (3) there is generally a trend of increased LILE content, as represented by $\mathrm{Rb}$, and the OFRE; and (4) the greisen samples generally plot away from the extensions of the enrichment trends 

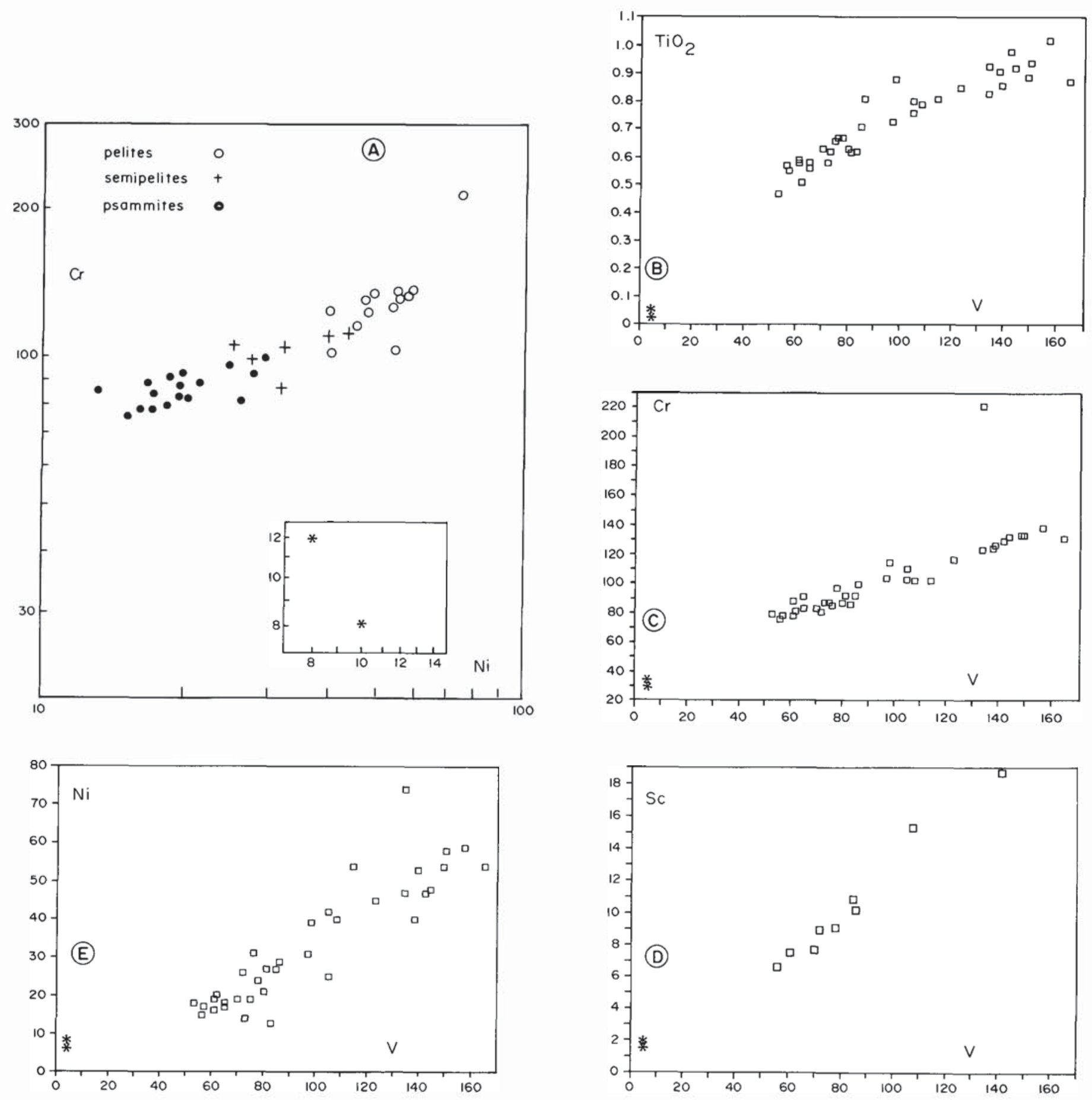

Fig. 9. Binary element diagrams for East Kemptville metasedimentary rocks $(\square)$ and greisens $\left({ }^{*}\right)$ (B,C,D,E) showing the covariation of ferromagnesian trace elements; note the excellent correlation in all plots with no dispersion of the data towards the greisen samples. Also note that in Figure 9A the data plot within the field (not outlined in diagram) for post-Archean fine-grained sedimentary rocks (from Taylor and McLellan, 1985).

defined by the metasedimentary data. These data would suggest that there is considerable enrichment of the OFRE in the metasedimentary rocks and that this enrichment is quite pervasive.

Arsenic shows no absolute enrichment compared to the background levels listed in Table 2. Only 3 of the 36 analyzed samples have $>100 \mathrm{ppm}$ As while the remaining are all $<50$ $\mathrm{ppm}$. This is noted because the general enrichment of As in mineralized zones within the ore deposit occurs in close proximity to the metasediment-granite contact, especially in the north end of the deposit (C. Poulin, personal communication, 1990). 

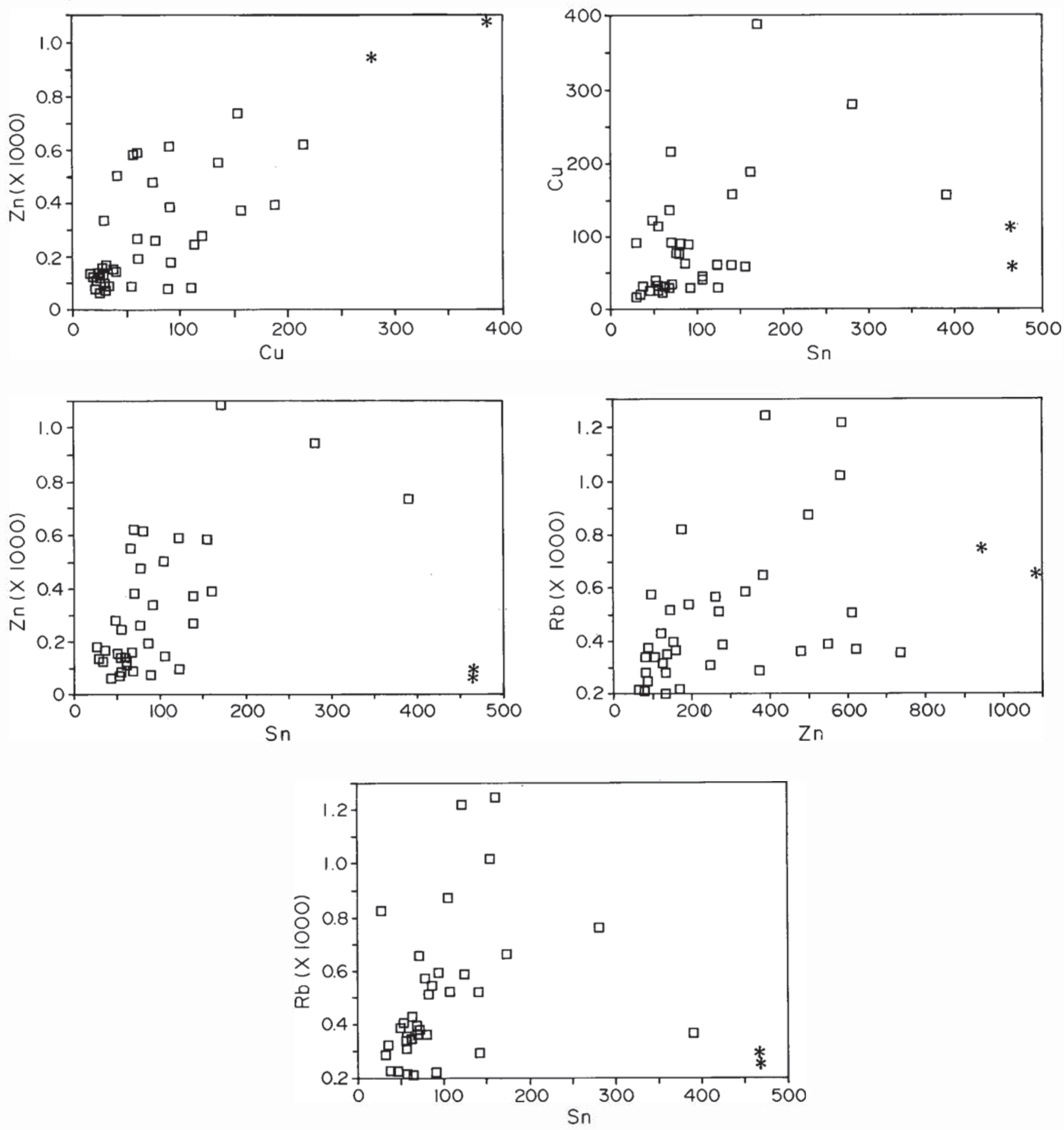

Fig. 10. Binary element diagrams for East Kemptville metasedimentary rocks $(\square)$ and greisens $\left({ }^{*}\right)$ showing the covariation of various ore forming elements (ORFE; $\mathrm{Cu}, \mathrm{Zn}, \mathrm{Sn}$ ) and $\mathrm{Rb}$ (representative of LIL elements in general). Note that there is a general tendency for the ORFE to behave compatibly, while $\mathrm{Rb}$ first increases and then rapidly decreases as the content of ORFE increases (e.g., $\mathrm{Zn}$, Sn).

\section{Rare-earth elements}

REE data have been obtained for 11 samples, including 2 pelites, 1 semipelite and 6 unaltered psammites and the 2 greisens. The data are presented in Table 3 , including the significant ratios (e.g., $\left.(\mathrm{La} / \mathrm{Lu})_{N}, \mathrm{Eu} / \mathrm{Eu}^{*}\right)$, and the chondrite- normalized profiles are illustrated in Figure 11. As already noted above, the apparent inflections at Gd in the chondritenormalized profiles for all the samples, especially the two greisen samples, are anomalous and attributed to analytical problems. However, since the Gd inflection is not great in the metasedimentary rocks (e.g., from extrapolating between 


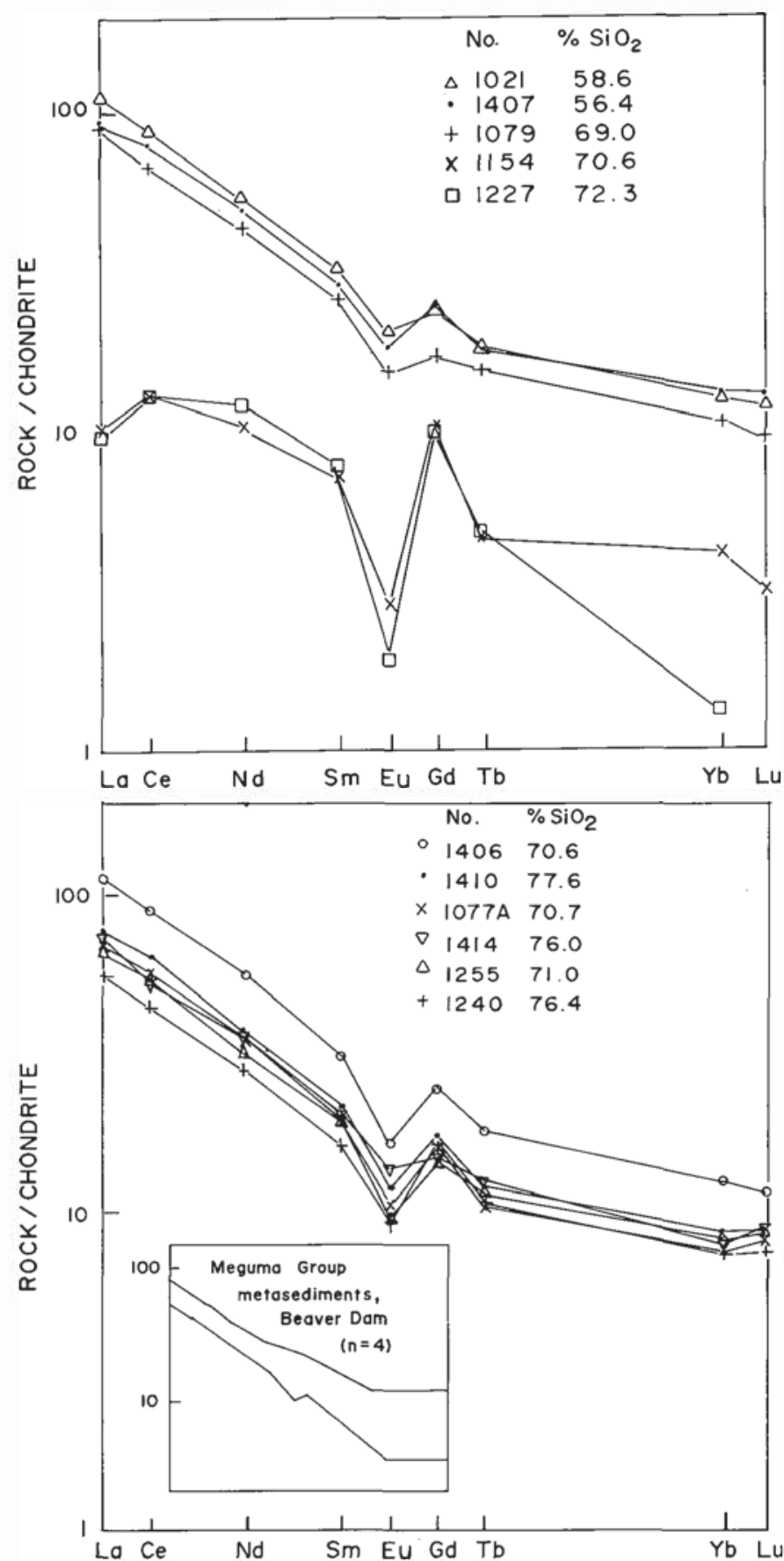

Fig. 11. Chondrite-normalized rare-earth element diagrams for East Kemptville metasedimentary rocks and greisens (EK-86$1154,1227)$. The inset diagram shows the chondrite-normalized profiles for unaltered Meguma Group metasedimentary rocks from the Beaver Dam area (unpublished data of Kontak). Note the extreme depletions of the REE in the greisen samples and the generally consistent patterns for the variably mineralized metasedimentary rocks.

Tb-Sm), it is not considered to influence significantly the ratios discussed [e.g., $(\mathrm{Gd} / \mathrm{Yb})_{\mathrm{N}}$ ].

The metasedimentary rocks have typical REE abundances and patterns for fine-grained, post-Archean sediments (e.g., Haskin et al., 1966; Nance and Taylor, 1976;
Taylor and McLellan, 1985; Grauch, 1989; McLellan, 1989; McLellan and Taylor, 1991), including metaturbidites (Nathan, 1976; Cullers et al., 1974; Jenner et al., 1981; Floyd and Leveridge, 1987; Feng and Kerrich, 1990) with $\Sigma$ REE (ppm) of $154 \pm 10,127$ and $109 \pm 25$ for pelites, semipelite and psammites (unaltered), respectively and $(\mathrm{La} / \mathrm{Lu})_{\mathrm{N}}=8.7 \pm 1.6$ for the pelites and $8.6 \pm 0.8$ for the psammites. The Eu/Eu* values are similar in all the metasedimentary rocks at 0.57 to 0.77 and $(\mathrm{Gd} / \mathrm{Yb})_{\mathrm{N}}<2$ in the fresh sediments; both values are typical for post-Archean metaturbidites (Fig. 12; McLellan, 1989; McLellan and Taylor, 1991). The REE patterns for the East Kemptville metasedimentary rocks also resemble those of other Meguma Group metasedimentary rocks (see inset in Fig. 11) within the central and eastern Meguma Terrane (Liew, 1978; Muecke and Clarke, 1981; Kontak, unpublished data).

For the two greisens there are several differences compared to the metasedimentary REE data: (1) depletion of the $\sum$ REE of $25 \mathrm{ppm}$; (2) an increase in the Eu anomaly (0.210.32 for $\mathrm{Eu} / \mathrm{Eu}^{*}$ ); and (3) a convex shape to the LREE pattern which is enhanced by depletion in La. However, compared to the REE data for the leucogranites (Kontak, 1990a), there is general consistency, except for the inflection at Gd, indicating that at least for the two samples analyzed there has been limited mobility of the REE during hydrothermal alteration.

\section{Geochemical Profiles in the Metasedimentary Rocks}

The samples located in Figure 3 have been grouped into three profiles referred to as A, B and C. The following comments are noted with respect to these profiles: (1) profile $\mathrm{C}$ includes all the samples along the granite-metasedimentary rock contact progressing from the south side (i.e., starts with sample 1021) and moving counter-clockwise around the granite-sediment contact (i.e., finishes with sample 1027). This profile also includes the two roof pendent samples (1021, 1079; see Fig. 3b); (2) profile A and C include the two greisen samples (1154 and 1227, respectively); (3) profile B includes samples 1239 and 1240 as the NW extension continuing from sample 1415 (see Fig. 3b); and (4) sample 1401 forms part of profile A (after samples 1154 and 1402).

The geochemical data are presented in these three profiles in Figure 13 in order to evaluate the potential relationship between elemental abundance and proximity to the granite. The $\mathrm{SiO}_{2}$ profile illustrates the typical intercalated nature of the pelitic to psammitic lithologies and the variable thickness of units (e.g., section B). There is a decrease in absolute $\mathrm{Rb}$ content away from the granite when profiles $\mathrm{A}$ and $B$ are compared to profile $C$. The relative enrichment of $\mathrm{Rb}$ in this profile is again noted with respect to the ORFE $(\mathrm{Cu}$, $\mathrm{Zn}, \mathrm{Sn}, \mathrm{As}$ ). For $\mathrm{Cu}$ and $\mathrm{Zn}$, and to a lesser degree As, profile $\mathrm{C}$ is consistently enriched compared to the other profiles. Interestingly, the greatest enrichment in $\mathrm{Sn}$ is found for two samples from profile $\mathrm{B}$, although on average profile $\mathrm{C}$ again has a greater relative enrichment compared to sample from profiles A and B. 


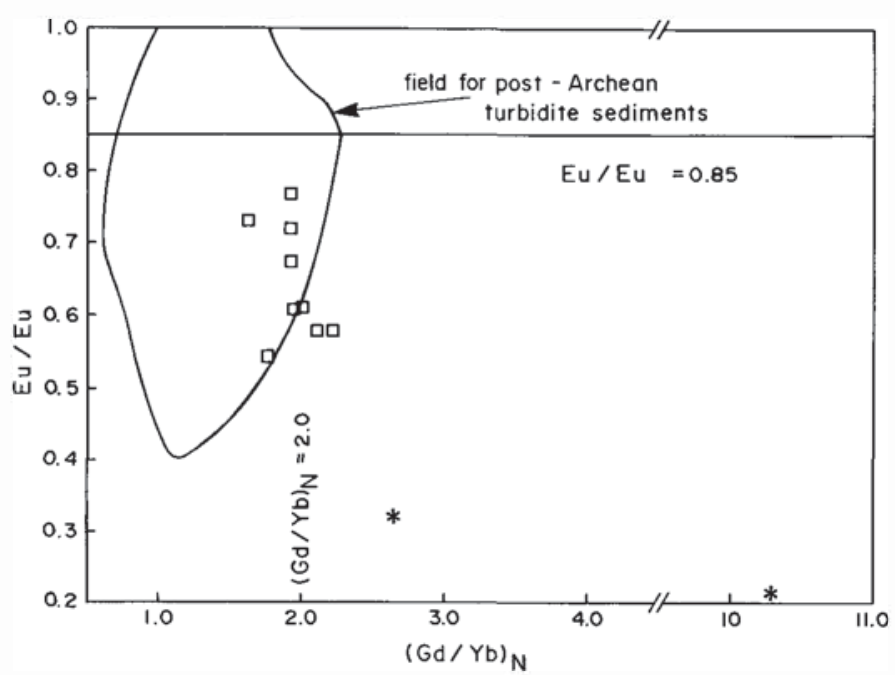

Fig. 12. Plot of Eu/Eu* versus $(\mathrm{Gd} / \mathrm{Yb})_{\mathrm{N}}$ for metasedimentary rocks $(\square)$ and greisens (*) from East Kemptville comparing data to the field for post-Archean turbidite sediments (McLellan, 1989; McLellan and Taylor, 1991). See text for discussion.

\section{Discussion}

The emplacement of intrusive rocks into upper crustal levels generally results in the development of hydrothermal convection cells that promote the circulation of heated waters during the cooling history of the intrusion. The result of this hydrothermal activity is the formation of certain hydrothermal mineral deposits, especially massive sulphides (Franklin et al., 1981), Cu-Mo porphyries (Titley and Beane, 1981; White et al., 1981) and skarns (Einaudi et al., 1981; Kwak, 1987). That such cells occur and involve the introduction of magmatic-derived fluids is well documented from the study of stable isotopes (Taylor, 1974, 1978), fluid inclusions (Roedder, 1984), petrological investigations (Ferry, 1978) and integrated studies (e.g., Gerstner et al., 1989; Novick and Labotka, 1990). By analogy to this aforementioned work and the well-established capacity for granites to exsolve fluids late in their crystallization history (e.g., Burnham, 1979), it is reasonable to expect that there has been movement of fluid from the leucogranite at East Kemptville through the surrounding metasedimentary rocks. There have, however, been few detailed studies that have documented the magnitude of fluid flow and elemental enrichment resulting from infiltration of magmatic-derived fluids (Cathles, 1981).

In the case of Sn deposits, two recent studies focused on the extent of primary dispersion about mineralized centres are particularly relevant to this investigation because of the similarity of geological setting and mineralization. Polya $(1987,1988)$ examined the dispersion of $\mathrm{Sn}, \mathrm{W}, \mathrm{Zn}, \mathrm{Cu}$ and As around the Panasqueira ore body, Portugal, and found that the pelitic schists surrounding the deposit contain anomalous values of these elements (see Table 2) up to $8 \mathrm{~km}$ from the mineralized centre. Polya (1987) also estimated that $>90 \%$ of the metals, except for W ( 30\%), are dispersed around the deposit. Meanwhile, Beer and Ball (1986) showed that of the five mineralized centres studied in southwest England, $\mathrm{Sn}$ is enriched in the surrounding metasedimentary rocks, and to a lesser extent $\mathrm{W}$, up to at least $1 \mathrm{~km}$ from the known point source.

In the case of the East Kemptville deposit area, the lithogeochemical data indicate that there has been little modification of the major element chemistry and most of the trace element chemistry. For example, in terms of the major elements, comparison to either the average chemical signature of unmineralized Meguma Group rocks (Fig. 7) or binary discriminant diagrams (Fig. 6) indicates that the metasedimentary rocks appear unaltered. For the trace elements, use of discriminant diagrams [e.g., Th/Sc/Zr, $\mathrm{La} / \mathrm{Th} / \mathrm{Sc}$ (Bhatia and Crook, 1986) or La-Th, Sc-Th (McLellan, 1989); note that these diagrams are not shown] and comparison to the unmineralized data base for the Meguma Group (Fig. 7) indicate little mobility or enrichment for most elements. However, for $\mathrm{Sn}, \mathrm{U}, \mathrm{Rb}, \mathrm{Li}$ and $\mathrm{Zn}$ there is variable enrichment compared to typical background values in metasedimentary rocks (Table 2) and also compared to the average values established for the Meguma Group (Fig. 7). Some other elements ( $\mathrm{Bi}, \mathrm{W}, \mathrm{Sb})$ may be slightly enriched but higher detection limits do not permit an unambiguous conclusion.

To further examine the spatial relationship of elemental enrichment profiles about the granite were constructed. These profiles (Fig. 13) indicate that generally speaking there is slight enrichment of some elements immediately adjacent to the granite. However, the general absence of veins in the metasedimentary rocks containing ore minerals (e.g., cassiterite, sphalerite) suggests that the elemental enrichment may reflect the presence of fine-grained, disseminated minerals and/or variable amounts of substitution within the secondary micaceous minerals (e.g., muscovite). In either case, the profiles indicate that both the amount and extent of enrichment within the metasedimentary rocks is exceptionally limited compared to the examples cited above.

The general positive correlation among and between the elevated trace elements suggest that their enrichment is related to a single hydrothermal event. Petrographically this enrichment is manifested by the highly variable amount and growth of new minerals. The development of white mica \pm other minerals, both as disseminations and along veinlets or microfractures, is the most commonly observed phenomenon and can account for the elevated $\mathrm{Rb}$ and $\mathrm{Li}$ values. Additional observations include: (1) the growth of chlorite, tourmaline, fluorite, cassiterite and other ore minerals, and (2) the alteration of biotite. The presence of tourmaline in the metasedimentary rocks is noted because of its absence in the local granite.

The processes responsible for the elemental enrichment may have preceded the main mineralizing event at East Kemptville and, therefore, reflect expulsion of early-stage orthomagmatic fluids or, conversely, the elemental enrichment may be related to the same fluids which later were responsible for the main $\mathrm{Sn}$ and base metal mineralization. We have no way of distinguishing between these two scenarios, but consider the latter to be more plausible. 
CU PROFILE

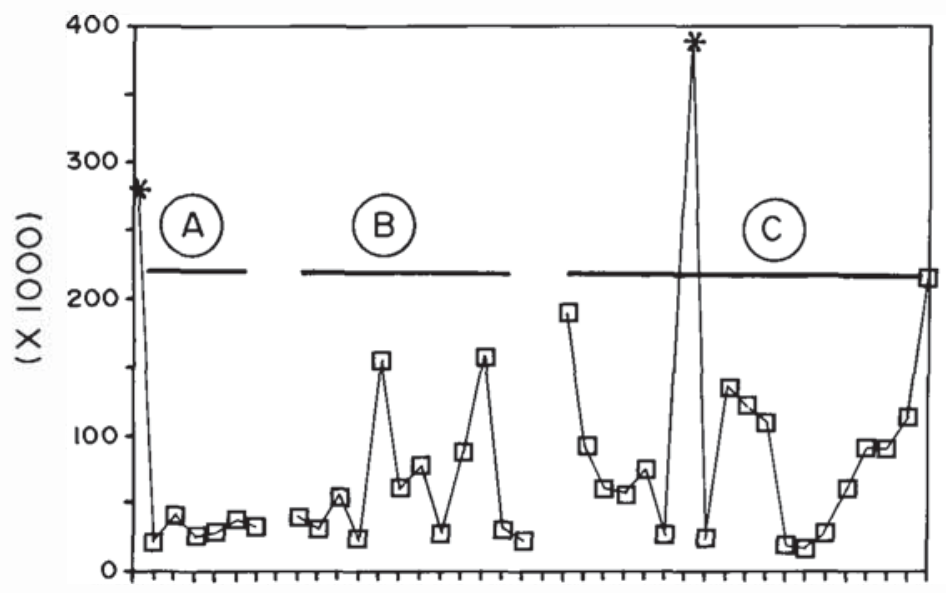

As PROFILE

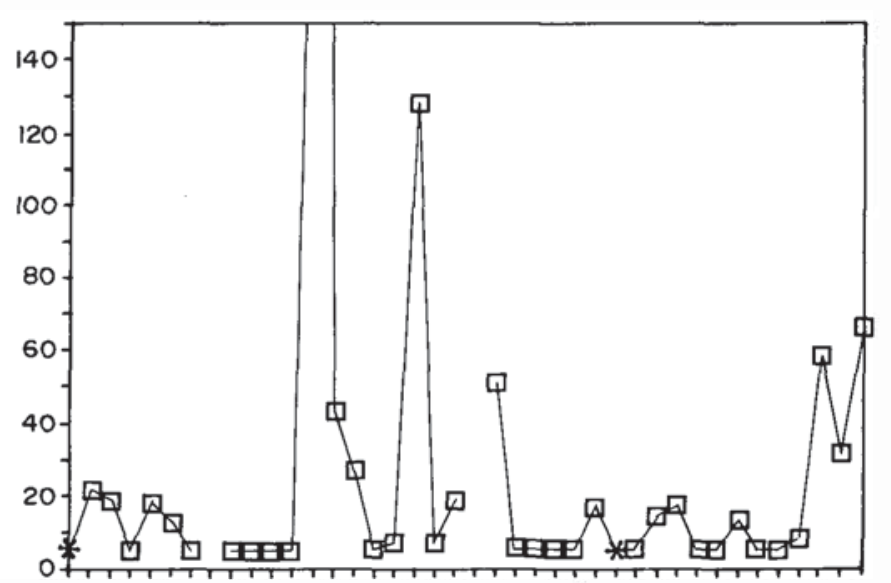

Zn PROFILE

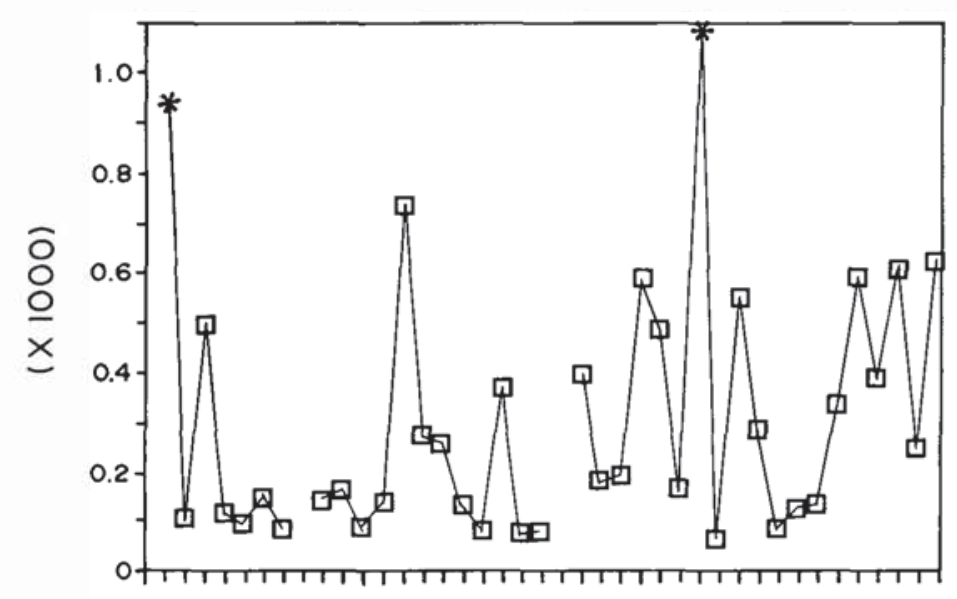

Sn PROFILE

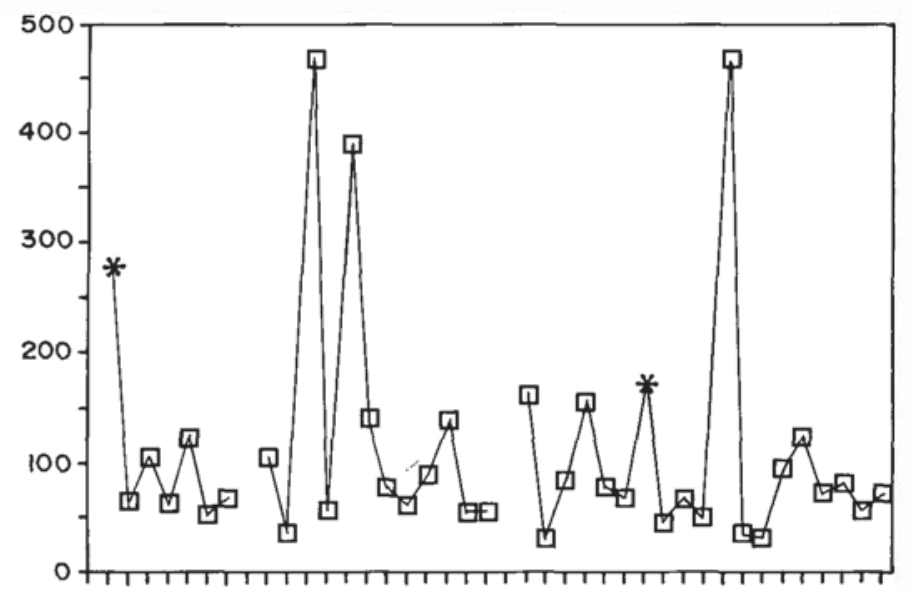

Rb PROFILE

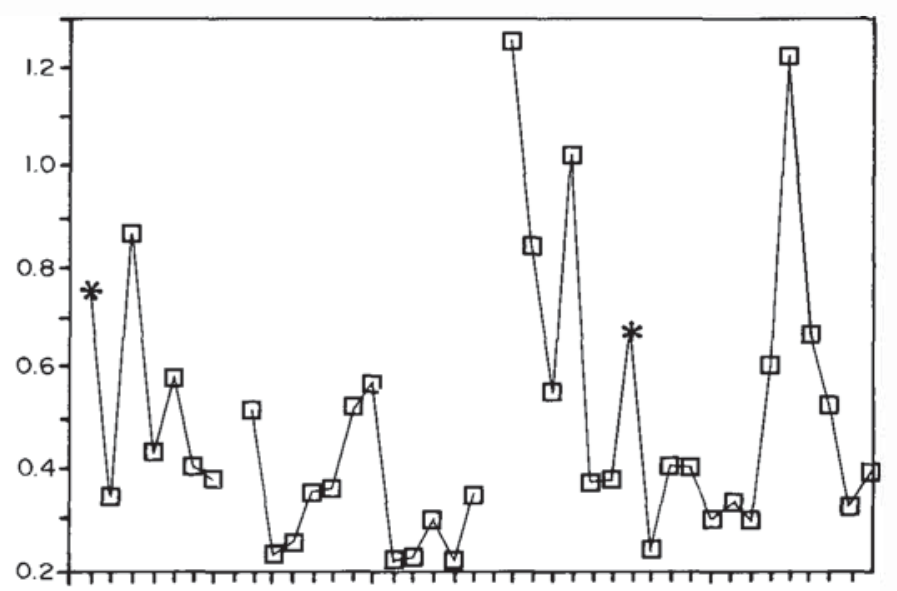

Fig. 13. Geochemical profiles of elements ( $\mathrm{Cu}, \mathrm{As}, \mathrm{Zn}, \mathrm{Sn}, \mathrm{Si}, \mathrm{Rb}$ ) in the country rocks at the East Kemptville Sn deposit. See Figure 3 for location of the profiles. Note that profile $\mathrm{C}$ is for rocks from along the granite-sediment contact starting with samples along south side of the deposit area in Figure 3. The two greisen samples are included in the profiles and indicated by the appropriate symbol $\left({ }^{*}\right)$. 
The lack of visible, bona fide veinlets in the metasedimentary rocks, combined with the generally fine-grained, disseminated nature of muscovite suggests that fluids were transported through the sediments along microfractures, grain boundaries or a structural anisotropy such as cleavage. This contrasts, for example, with the richly mineralized metasedimentary-hosted Sn-W-base metal veins of the Central Andean tin belt (e.g., Palma and Clark, 1982) where large fissure veins acted as fluid channelways for magmatically-derived, metal-bearing fluids. In any event, hydrofracturing was clearly not the preferred mechanism for dispersal of fluid at East Kemptville. Although there is clearly evidence of infiltration of a granite-derived fluid, the metasedimentary rocks may still be considered to have acted as a relatively impermeable trap for the mineralizing fluids as Richardson et al. (1982) originally suggested. This process would have the effect of promoting build up of a fluid reservoir and this would have enhanced the development of mineralization within the granite.

Evidence that a hydrothermal circulation cell was present at East Kemptville may be examined in light of isotopic studies done at the deposit (Kontak, 1988, 1990b). Neither S nor $\mathrm{O}$ isotope data indicate that an externally-derived fluid equilibrated with the metasedimentary rocks infiltrated the granite, while $\mathrm{Sr}$ isotopic data (Richardson et al., 1990b) proved inconclusive is discerning what the role, if any, of the metasedimentary rocks played in terms of the deposit. In addition, although the presence of graphite of hydrothermal origin occurs in the mineralized greisens (Kontak, 1988), we have no idea how it entered the mineralizing system or at what structural level.

Finally, the lack of Mn-enrichment, either chemically and mineralogically, indicates that the manganiferous GHT horizon has not played a significant role in the genesis of the East Kemptville tin deposit, as suggested by Sangster (1990). The stratigraphy, bulk rock chemistry and mineralogy contrasts, for example, with that observed at the Duck Pond deposit (Hattie, 1989; Pitre and Richardson, 1989; Kontak et al., 1990), where the GHT horizon is present.

\section{Conclusions}

A lithogeochemical and petrographic study of 36 samples of metasedimentary rocks from the East Kemptville deposit area indicates that a primary dispersion halo exists. Although the rocks appear relatively unaltered and highly indurated, petrographic evidence suggestive of fluid passage includes the presence of fine-grained, disseminated muscovite and lesser amounts of coarser fracture-controlled muscovite, chlorite, tourmaline, cassiterite, ore minerals, fluorite, topaz and carbonate. Geochemically the rocks are characterized by normal major element chemistry when compared to the average for unaltered Meguma Group rocks of similar lithology. With regards to the trace elements, the REE, HFSE and most transition or ferromagnesian elements retain apparently primary elemental abundances. However, there is appreciable enrichment of some LILE ( $\mathrm{Rb}, \mathrm{Li}, \mathrm{U})$ and ore elements ( $\mathrm{Sn}$,
$\mathrm{Zn}$ ) which reflects infiltration of the ore fluid from the adjacent mineralized granite/greisen. Although fluid did infiltrate and interact with the metasediments, transport must have been restricted to microfractures, grain boundaries and planar fabrics such as cleavage, as no fissure veins are present. Consequently, fluid flow may have been retarded which would have favoured the build up of fluid within the granite carapace and promoted the mineralizing process as originally suggested by Richardson et al. (1982).

\section{Acknowledgements}

Field work at the East Kemptville deposit by D. Kontak has been funded through Canada-Nova Scotia Mineral Development Agreements (1984-1989, 1990-1992) and the cooperation and support of the personnel at Rio Kemptville Tin Corporation is sincerely acknowledged. Funding for the analyses for this project were provided by the CNSMDA and National Science and Engineering Research Council grant to J. Dostal. The capable assistance in manuscript preparation by personnel at the Nova Scotia Department of Natural Resources is once again appreciated. Comments on the manuscript by D. Mossman and R. Raeside contributed to improvements and are appreciated. This paper is published with permission of the Director of the Mineral Resources Division, Nova Scotia Department of Natural Resources.

BeER, K.E. and BALL, T.K. 1986. Tin and tungsten in pelitic rocks from S.W. England and their behaviour in contact zones of granites and in mineralized areas. Proceedings of the Ussher Society, 6, pp. 330-337.

Bhatia, M.R. 1983. Plate tectonics and geochemical composition of sandstones. The Journal of Geology, 91, pp. 611-627.

_- 1985. Rare earth element geochemistry of Australian Paleozoic greywackes and mudrocks: provenance and tectonic control. Sedimentary Geology, 45, pp. 97-113.

BhatiA, M.R. and Crook, K.A.W. 1986. Trace element characteristics of greywackes and tectonic setting discrimination of sedimentary basins. Contributions to Mineralogy and Petrology, 92, pp. 181-193.

Burnham, C.W. 1979. Magmas and hydrothermal fluids. In Geochemistry of Hydrothermal Ore Deposits. Edited by H.L. Barnes. John Wiley and Sons, New York, pp. 71-136.

Cameron, E.M. and Garrels, R.M. 1980. Geochemical compositions of some Precambrian shales from the Canadian shield. Chemical Geology, 28, pp. 181-197.

CAtHLES, L.M. 1981. Fluid flow and genesis of hydrothermal ore deposits. Economic Geology, 75th Anniversary Volume, pp. 424-457.

Chatterjee, A.K. 1983. Metallogenic map of Nova Scotia. Nova Scotia Department of Mines and Energy map, scale 1:500,000 .

Chatterjee, A.K. and Strong, D.F. 1984. Rare-earth and other element variations in greisens and granites associated with East Kemptville tin deposit, Nova Scotia, Canada. Transactions Institute of Mining and Metallurgy, 93, pp. 359-370.

Chatterjee, A.K., Strong, D.F., and Clarke, D.B. 1985. Petrology of the polymetallic quartz-topaz greisen at East Kemptville. In Guide to the Granites and Mineral Deposits of 
Southwestern Nova Scotia. Edited by A.K. Chatterjee and D.B. Clarke. Nova Scotia Department of Mines and Energy, Paper 85-3, pp. 153-196.

Clarke, D.B. and Halliday, A.N. 1980. Strontium isotope geology of the South Mountain Batholith, Nova Scotia. Geochimica et Cosmochimica Acta, 44, pp. 1045-1058.

Cullers, R.L., Yeh, L.T., and Chaudhuri, S. 1974. Rare earth elements in Silurian pelitic schists from N.W. Maine. Geochimica et Cosmochimica Acta, 38, pp. 389-400.

Dostal, J., Baragar, W.R.A., and DupuY, C. 1986. Petrogenesis of the Natkusiak continental basalts, Victoria Island, Northwest Territories, Canada. Canadian Journal of Earth Sciences, 23, pp. 622-632.

Einaudi, M.T., Meinert, L.D., and Newber Ry, R.J. 1981. Skam deposits. Economic Geology, 75th Anniversary Volume, pp. 317-391.

Feng, R. and Kerrich, R. 1990. Geochemistry of fine-grained clastic sediments in the Archean Abitibi greenstone belt, Canada: implications for provenance and tectonic setting. Geochimica et Cosmochimica Acta, 54, pp. 1061-1081.

FERRY, J.M. 1978. Fluid interaction between granite and sediment during metamorphism, south-central Maine. American Journal of Science, 278, pp. 1025-1056.

FLoyd, P.A. and Leveridge, B.E. 1987. Tectonic environment of the Devonian Gramscatho basin, south Cornwall: framework mode and geochemical evidence from turbiditic sandstones. Journal of the Geological Society London, 144, pp. 531-542.

Franklin, J.M., Sangster, D.M., and Lydon, J.W. 1981. Volcanic-associated massive sulfide deposits. Economic Geology, 75th Anniversary Volume, pp. 485-627.

Gerstner, M.R., Bowman, J.R., and Pasteris, J.D. 1989. Skarn formation at the MacMillan Pass tungsten deposit (MacTung), Yukon and Northwest Territories. I. P-T-X characterization of the methane-bearing, skarn-forming fluids. Canadian Mineralogist, 27, pp. 545-563.

GRAUCH, R.I. 1989. Rare earth elements in metamorphic rocks. In Geochemistry and Mineralogy of Rare Earth Elements. Edited by B.R. Lipin and G.A. McKay. The Mineralogical Society of America, Reviews in Mineralogy, 21, pp. 147-168.

Gromet, L.P., Dymek, R.F., Haskin, L.A., and Korotev, R. 1984. The "North American shale composite": Its composition, major and trace element characteristics. Geochimica et Cosmochimica Acta, 48, pp. 2469-2482.

Haskin, L.A., Wildeman, T.R., Frey, F.A., Collins, K.A., Keedy, C.R., and HASKIN, M.A. 1966. Rare earths in sediments. Journal of Geophysical Research, 71, pp. 6091-6105.

Hattie, K.J. 1989. Petrography and surface geology of the Duck Pond Zone Sediment-hosted tin prospect, Yarmouth County, Nova Scotia. Unpublished B.Sc. thesis, Mount Allison University, Sackville, New Brunswick.

JenNer, G.A., Fryer, B.J., and McLellan, S.M. 1981. Geochemistry of the Archean Yellowknife Supergroup. Geochimica et Cosmochimica Acta, 45, pp. 1111-1129.

Keppie, J.D. 1982. The Minas Geofracture. In Major Structural Zones and Faults of the Northern Appalachians. Edited by P. St.-Juliean and J. Beland. Geological Association of Canada, Special Paper 24, pp. 263-280.

Keppie, J.D. and DallmeyeR, R.D. 1987. Dating transcurrent terrane accretion: an example from the Meguma and Avalon composite terranes in the northern Appalachians. Tectonics, 6, pp. 831-847.

KonTAK, D.J. 1988. The East Kemptville project: whole-rock and mineral chemistry, stable isotopes and fluid inclusion studies - a progress report. In Mines and Minerals Branch Report of Activities 1988, Part A. Edited by D.R MacDonald and Y. Brown. Nova Scotia Department of Mines and Energy, Report 88-3, pp. 83-96.

1990a. The East Kemptville topaz-muscovite leucogranite, Nova Scotia: I. Geological setting and whole-rock geochemistry. Canadian Mineralogist, 28, pp. 787-825.

1990b. A sulfur isotopic study of main-stage tin and base metal mineralization at the East Kemptville tin deposit, Yarmouth County, Nova Scotia, Canada: evidence for magmatic origin of metals and sulfur. Economic Geology, 85, pp. 399-407.

1990c. A geological and geochemical study of the East Kemptville Sn-Zn-Cu-Ag deposit, southern Nova Scotia, Canada: mineralization hosted by a ca. $370 \mathrm{Ma}$ topaz-muscovite leucogranite. In Program with Abstracts, 8th IAGOD Symposium, Ottawa, Ontario, p. 34.

1991. The East Kemptville topaz-muscovite leucogranite, Nova Scotia: II. Mineral chemistry. Canadian Mineralogist, 29 , pp. $37-60$.

In press. Geological, geochemical and isotopic studies of the East Kemptville (Sn-Zn-Cu-Ag) deposit, Yarmouth County, Nova Scotia, Canada. Proceeding of the Eighth Quadrennial IAGOD Symposium, E. Schweizerbart'sche Verlagsbuchhandlung, Stuttgart, Germany.

Kontak, D.J. and Chatterjee, A.K. In press. The East Kemptville tin deposit, Yarmouth County, Nova Scotia III. A Pb isotope study of the leucogranite and mineralized greisen: Evidence for a $366 \mathrm{Ma}$ metallogenic event. Canadian Journal of Earth Sciences, 29.

Kontak, D.J. and Cormier, R.F. 1991. A Rb/Sr geochronological study of the East Kemptville leucogranite, East Kemptville tin deposit, Yarmouth County, Nova Scotia: evidence for multiple tectono-thermal overprinting events. Canadian Journal of Earth Sciences, 28, pp. 209-224.

Kontak, D.J., Mulja, T., and Hingston, R. 1986. The East Kemptville Sn deposit: preliminary results from recent mapping. In Tenth Annual Open House and Review of Activities. Edited by J.L. Bates and D.R. MacDonald. Nova Scotia Department of Mines and Energy, Information Series No. 12, pp. 97-103.

Kontak, D.J., O'Reilly, G.A, and Chatteriee, A.K. 1990. The southwest Nova Scotia tin domain, Yarmouth County, Nova Scotia: implications for tin metallogeny in the Meguma Terrane, Nova Scotia. In Mines and Minerals Branch Report of Activities 1989, Part B. Edited by D.R. MacDonald. Nova Scotia Department of Mines and Energy, Report 90-1, pp. 1332.

KwaK, T.A.P. 1987. W-Sn Skarn Deposits and Related Metamorphic Skarns and Granitoids. Elsevier, Amsterdam, 451 p.

Liew, M.Y.C. 1978. Geochemical Studies of the Goldenville Formation at Taylor Head, Nova Scotia. Unpublished M.Sc. thesis, Dalhousie University, Halifax, Nova Scotia.

MAAs, R. and MCCulLOCH, M.T. 1991. The provenance of Archean clastic metasediments in the Narryer Gneiss Complex, western Australia: Trace element geochemistry, Nd isotopes, and $\mathrm{U}-\mathrm{Pb}$ ages for detrital zircons. Geochimica et Cosmochimica Acta, 55, pp. 1915-1932.

MacDonald, M.A., Corey, M.C., Ham, L.J., and Horne, R.J. 1989. Petrographic and geochemical aspects of the South Mountain Batholith. In Mines and Minerals Branch Report of 
Activities 1989, Part A. Edited by D.R. MacDonald and K.A. Mills. Nova Scotia Department of Mines and Energy, Report 89-3, pp. 75-80.

Ma cDonald, M.A., Horne, R.J., Corey, M.C., and Ham, L.J. 1992. An overview of recent bedrock mapping and follow-up petrological studies of the South Mountain Batholith, southwestern Nova Scotia, Canada. Atlantic Geology, 28, pp. $7-$ 28.

Mawer, C. and White, J.C. 1987. Sense of displacement on the Cobequid-Chedabucto Fault system, Nova Scotia, Canada. Canadian Journal of Earth Sciences, 24, pp. 217-223.

MCLellan, S.M. 1989. Rare earth elements in sedimentary rocks: influence of provenance and sedimentary processes. In Geochemistry and Mineralogy of Rare Earth Elements. Edited by B.R.Lipin and G.A. McKay. Mineralogical Society of America, Reviews in Mineralogy, 21, pp. 169-200.

McLellan, S.M. and TAYLOR, S.R. 1991. Sedimentary rocks and crustal evolution: tectonic setting and secular trends. Journal of Geology, 99, pp. 1-21.

Moy LE, J.E. 1985. East Kemptville tin project. In Guide to the Granites and Mineral Deposits of Southwestern Nova Scotia. Edited by A.K. Chatterjee and D.B. Clarke. Nova Scotia Department of Mines and Energy, Paper 85-3, pp. 199-200.

Muecke, G. and Clarke, D.B. 1981. Geochemical evolution of the South Mountain Batholith, Nova Scotia: rare-earth-element evidence. Canadian Mineralogist, 19, pp. 133-146.

Muecke, G.K., Elias, P., and Reynolds, P.H. 1988. Hercynian/ Alleghanian overprinting of an Acadian Terrane: ${ }^{40} \mathrm{Ar} /{ }^{39} \mathrm{Ar}$ studies in the Meguma Terrane, Nova Scotia, Canada. Chemical Geology, 73, pp. 153-167.

NANCE, W.B. and TAYLOR, S.R. 1976. Rare earth element patterns and crustal evolution-I. Australian post-Archean sedimentary rocks. Geochimica et Cosmochimica Acta, 40, pp. 15391551.

Nathan, S. 1976. Geochemistry of the Greenland Group (Early Ordovician), New Zealand. New Zealand Journal of Geology and Geophysics, 19, pp. 683-706.

Novick, J.S. and LABOtKA, C. 1990. Metamorphic fluids in the Notch Peak contact-metamorphic aureole: Evidence from fluid inclusions. American Mineralogist, 75, pp. 387-391.

Palma, V. and Clark, A.H. 1982. The San Rafael tin-copper system, S.E. Peru: a Cornwall-type deposit in the Central Andean belt. Geological Association of Canada, Program with Abstracts, 7, p. 71.

PAn, Y., Fleet, M., and Stone, W.E. 1991. Geochemistry of metasedimentary rocks in the late Archean Heron Bay greenstone belt, Superior Province, Ontario: implications for provenance and tectonic setting. Precambrian Research, 52, pp. 53 69.

Pitre, C. and Richardson, J.M. 1989. Paragenesis of veins of the Duck Pond tin prospect, Meguma Group, East Kemptville, Nova Scotia. Canadian Journal of Earth Sciences, 26, pp. 2031-2043.

PolyA, D.A. 1987. Chemical Behaviour of Tungsten in Hydrothermal Fluids and Genesis of the Panasqueira W-Cu-Sn Deposit, Portugal. Unpublished Ph.D. thesis, University of Manchester, Manchester, England.

1988. Efficiency of hydrothermal ore formation and the Panasqueira W-Cu(Ag)-Sn vein deposit. Nature, 333, pp. 838-841.

Poole, W.H. 1967. Tectonic evolution of Appalachian region of Canada. Geological Association of Canada, Special Paper 4, pp. 9-51.

ReYNolds, P.H. and Murcke, G.K. 1978. Age studies on slates: applicability of the ${ }^{40} \mathrm{Ar} /{ }^{39} \mathrm{Ar}$ stepwise outgassing method. Earth and Planetary Science Letters, 40, pp. 111-118.

Reynolds, P.H., Zentilli, M., and Muecke, G.K. 1981. K-Ar and ${ }^{40} \mathrm{Ar} /{ }^{39} \mathrm{Ar}$ geochronology of granitoid rocks from southern Nova Scotia: its bearing on the geological evolution of the Meguma Zone of the Appalachians. Canadian Journal of Earth Sciences, 18, pp. 386-394.

Richardson, J.M. 1983. Geology and geochemistry of the East Kemptville greisen-hosted tin deposit, Yarmouth County, Nova Scotia. Unpublished M.Sc. thesis, University of Toronto, Toronto, Ontario, 232 p.

-1988. Field and textural relationships of alteration and greisen-hosted mineralization at the East Kemptville tin deposit, Davis Lake Complex, southwest Nova Scotia. In Recent Advances in the Geology of Granite-Related Mineral Deposits. Edited by R.P. Taylor and D.F. Strong. Canadian Institute of Mining and Metallurgy, 39, pp. 265-279.

Richardson, J.M., Spooner, E.T.C., and McAuslan, D.A. 1982. The East Kemptville tin deposit, Nova Scotia: an example of a large tonnage, low grade, greisen-hosted deposit in the endocontact zone of a granite batholith. In Current Research, Part B, Geological Survey of Canada, Paper 82-1B, pp. 27 32.

Richardson, J.M., Bell, K., Blenkinsop, J., and Watkinson, D.H. 1988. Fluid saturation textures and $\mathrm{Rb}-\mathrm{Sr}$ isochron data from the East Kemptville tin deposit, southwestern Nova Scotia. In Current Research, Part B, Geological Survey of Canada, Paper 88-1B, pp. 163-171.

Richardson, J.M., Bell, K., Watkinson, D.H., and BlenkinSOP, J. 1990a. Genesis and fluid evolution of the East Kemptville greisen-hosted tin mine, southwestern Nova Scotia, Canada. In Ore-Bearing Granite Systems; Petrogenesis and Mineralizing Processes. Edited by H.J. Stein and J.L. Hannah. Geological Society of America, Special Paper 246, pp. 181-204.

Richardson, J.M., Blenkinsop, J., and Bell, K. 1990b. Extreme variations in strontium initial ratios in ore-related fluids. Contributions to Mineralogy and Petrology, 104, pp. 516529.

Roedder, E. 1984. Fluid Inclusions. American Mineralogist Reviews in Mineralogy, 12, 644 p.

Sangster, A.L. 1990. Metallogeny of the Meguma Terrane, Nova Scotia. In Mineral Deposit Studies in Nova Scotia Volume 1. Edited by A.L. Sangster. Geological Survey of Canada, Paper 90-8, pp. 115-162.

SAWYER, E.W. 1986. The influence of source rock type, chemical weathering and sorting on the geochemistry of clastic sediments from the Quetico metasedimentary belt, Superior Province, Canada. Chemical Geology, 55, pp. 77-95.

Scratch, R.B., Watson, G.P., Kerrich, R., and Hutchinson, R.W. 1984. Fracture-controlled antimony-quartz mineralization, Lake George deposit, New Brunswick: mineralogy, geochemistry, alteration, and hydrothermal regimes. Economic Geology, 79, pp. 1159-1186.

Soehl, T.P., O'Reilly, G.A., Clarke, D.B., and Reynolds, P.J. 1989. The graphite-bearing, Kempt Snare Lake greisenized leucogranite cupola, Yarmouth County, Nova Scotia. In Mines and Minerals Branch Report of Activities 1988, Part B. Edited by Y. Brown and D.R. MacDonald. Nova Scotia Department of Mines and Energy, Report 89-1, pp. 51-70. 
TAYLOR, H.P., Jr. 1974. The application of oxygen and hydrogen isotope studies to problems of hydrothermal alteration and ore deposition. Economic Geology, 69, pp. 843-883.

1978. Oxygen and hydrogen isotope studies of plutonic granitic rocks. Earth and Planetary Science Letters, 38, pp. 177-210.

TAYlor, S.R. and McLellan, S.M. 1985. The Continental Crust: Its Composition and Evolution. Blackwell, Oxford, 312 p.

Titley, S.R. and Beane, R.E. 1981. Porphyry copper deposits. Part. II. Hydrothermal alteration and mineralization. Economic Geology, 75th Anniversary Volume, pp. 214-269.

Vine, J.D. and Tourtelot, E.B. 1970. Geochemistry of black shale deposits - a summary report. Economic Geology, 65 , pp. 253-272.

White, W.H., Bookstrom, A.A., Kamilli, R.J., Ganster, M.W., Smith, R.P., RANTA, D.E., and Steininger, R.C. 1981.
Character and origin of Climax-type molybdenum deposits. Economic Geology, 75th Anniversary Volume, pp. 270-316.

WintsCh, R.P., Kvale, C.M., and Кisch, H.J. 1991. Open-system, constant-volume development of slaty cleavage, and strain-induced replacement reactions in the Martinsburg Formation, Lehigh Gap, Pennsylvania. Geological Society of America Bulletin, 103, pp. 916-927.

Wronkiewicz, D.J. and Condie, K.C. 1987. Geochemistry of Archean shales from the Witswatersrand Supergroup, South Africa: source-area weathering and provenance. Geochimica et Cosmochimica Acta, 51, pp. 2401-2416.

Zentilli, M., Graves, M.C., Mulja, T., and Macinnes, I. 1986. Geochemical characterization of the Halifax-Goldenville Transition of the Meguma Group of Nova Scotia: preliminary report. In Current Research, Part A, Geological Survey of Canada, Paper 86-1A, pp. 423-428. 